James Madison University

JMU Scholarly Commons

$12-20-2021$

\title{
More Alike Than Different: Student Perceptions of Academic Librarians by Genders and Subject Areas
}

\author{
Elizabeth Price \\ price2el@jmu.edu \\ Jody C. Fagan \\ James Madison University
}

Follow this and additional works at: https://commons.lib.jmu.edu/letfspubs

Part of the Library and Information Science Commons

\section{Recommended Citation \\ Elizabeth Price \& Jody Condit Fagan (2021) More Alike than Different: Student Perceptions of Academic Librarians by Genders and Subject Areas, The Reference Librarian, 62:3-4, 221-263, DOI: 10.1080/ 02763877.2021 .2008580}

This Article is brought to you for free and open access by the Libraries at JMU Scholarly Commons. It has been accepted for inclusion in Libraries by an authorized administrator of JMU Scholarly Commons. For more information, please contact dc_admin@jmu.edu. 


\title{
More alike than different: Student perceptions of academic librarians
}

\section{by genders and subject areas}

\author{
Elizabeth Price and Jody Condit Fagan \\ James Madison University \\ Libraries, James Madison University, Rose Library, \\ 1251 Carrier Drive, Harrisonburg, Virginia 22807, USA \\ price2el@jmu.edu; faganjc@jmu.edu \\ This is an Accepted Manuscript of an article \\ published by Taylor \& Francis in the journal The Reference Librarian, \\ available online: \\ https://www.tandfonline.com/doi/full/10.1080/02763877.2021.2008580
}

\section{Acknowledgments}

The authors would like to thank Hillary Ostermiller and Lara Sapp for their collaboration on the original data gathering and for their analysis and feedback on this manuscript.

\section{Declaration of interest statement}

No potential conflicts of interest reported by the authors. 


\section{More alike than different: Student perceptions of academic librarians by genders and subject areas}

This study explored differences in how undergraduate students of different genders and academic disciplines perceived academic librarians at a U.S. public university. No evidence indicated differences between students identifying as male or female, and few statistically significant differences were found among four Subject Areas (Arts, Humanities + Social Sciences, Business, Health + Education, and STEM). Our results have implications for local practice though they are not generalizable to other institutions. Despite a lack of significant findings, librarians should continue to explore ways to measure how students of different disciplines perceive academic libraries and/or librarians as valuable to their academic success.

Keywords: perceptions; academic librarians; disciplines; genders

Footnote: The authors contributed equally to this work but elected to deviate from the alphabetical norm to mitigate the effects of alphabetical discrimination in academia (Weber, 2018). 


\section{Introduction}

This article investigates the extent to which student perceptions of academic librarians might differ by gender identity and among academic disciplines, with a particular focus on business students. Previous articles presented a full review of the perceptions literature as well as survey results from three samples (librarians, faculty, and students) at a comprehensive master's university (Fagan et al., 2020, 2021a, 2021b, 2021c). We were curious how perceptions among students in our sample might differ by gender identity and college. The College of Business was of particular interest to one of the authors because assertions are often made about business students based on a mix of research studies and anecdotal experience: that they don't visit library spaces, that they underutilize the library's business resources, and that they don't do research (Haigh, 2013). While the extent to which our single-institution study might be generalized to other institutions is unknown, we hope to use what we learn to inform local practice and to add to the growing body of exploratory research into disciplinary differences. We also hope to inform the methodology of future research. Our research questions for this article are:

1. Are there differences by gender identity in how undergraduate students perceive academic librarians?

2. Are there differences among subject areas in how undergraduate students perceive academic librarians?

3. In what ways do students majoring in business differ from other majors in their perceptions of academic librarians?

4. How might differences affect local practice of librarianship? 


\section{Literature review}

The three studies that inspired this research agenda (Bickley \& Corrall, 2011; Fagan, 2003; Hernon \& Pastine, 1977) did not collect data about students' majors. Fagan (2003) collected, but did not analyze, gender data. Hernon and Pastine (1977) noted their results differed by "sex," but did not report what the differences were. In our earlier literature review regarding perceptions of academic librarians (Fagan et al., 2021a) we didn't identify any articles that specifically looked at student perceptions of academic librarians that analysed data across academic majors or gender identity.

For this study, we expanded our review. The literature review associated with this study (Fagan et al., 2021a) summarized findings related to student perceptions of gender and librarians; these were not specific to academic librarianship but addressed broader topics such as librarianship's status as a "feminine, service-oriented" profession resulting in lower recognition and pay (p. 41). How the gender identity of students affects their perceptions of academic librarians has not been much studied; only Bonnet and McAlexander (2013) offered a conclusion based on the gender identity of their participations that female users "would be expected to show greater responsiveness to efforts by librarians to be more approachable" at the reference desk (p. 344).

When reviewing the recent literature for student perceptions of academic librarians and gender identity, we set aside studies in non-Western settings because of differences in cultural norms. Using EBSCOhost's Academic Search Complete, Business Source Complete, Education Research Complete, and Library, Information Science, and Technology Abstracts (LISTA), we searched for SU academic libraries AND gender AND (student* OR undergrad*). Results were limited to peer-reviewed journals published since 2017, inclusive. This search returned 21 results when duplicates were removed. Using Google Scholar, we 
searched for students AND “academic libraries" AND gender, setting the timeframe to 2017 to present and excluding citations. The first 50 results were examined by hand. Across these two searches, articles were found concerning gender and leadership in academic libraries, welcoming transgender and gender non-conforming people, and academic library salary differences between men and women; however, no studies were found specifically concerning the gender of students and perceptions of librarians. The most relevant findings included:

- A 2018 study of a public state college concerning library use and student success analyzing proxy server logs found no significant differences between library users and non-users regarding their gender identity (male versus female only) (LeMaistre et al., 2018, p. 125).

- A 2018 study found that respondents identifying as women at the City University of New York were more likely to "get help from CUNY Libraries staff to borrow or return library items" (p. 72) but found no gender difference in library resource usage, "such as borrowing books, reading e-books, and using e-resources" (Albarillo, 2018, p. 79).

A few articles called for libraries to improve services for transgender and LGBT+ people, offering suggestions for doing so (Krueger \& Matteson, 2017; Matheson et al., 2020; Wexelbaum 2018). Gender identity was included as an aspect within these articles.

As we had found no articles directly concerning disciplinary differences in student perceptions of academic librarians, we broadened our search to explore how different academic majors used or perceived library services as undergraduate students. Using EBSCOhost's Academic Search Complete, Business Source Complete, Education Research Complete, and Library, Information Science, and Technology Abstracts (LISTA), we 
searched for SU academic libraries AND (“subject area” OR Major) AND (student* OR undergrad*) NOT SU “graduate students.” Results were limited to peer-reviewed journals published since 2010. That search returned 177 results with duplicates removed. In Google Scholar, we searched for "academic libraries" AND ("subject area" OR "academic major" OR “course of study”) AND (undergrad*) AND survey, setting the timeframe to 2010 to present and excluding citations. More than 2,900 results were returned. Through handsearching and reviewing related articles in Google Scholar, we identified 16 studies that we considered relevant. We intentionally excluded articles that closely examined specific student populations (e.g., international students, pre-med students, students with disabilities, etc.) because their specificity would make them difficult to compare.

Studies that examine undergraduate student majors in the context of academic libraries usually aim to measure whether utilization of library services affects academic outcomes like retention, graduation, or grade point average (GPA). Library services vary in their scope across these studies and might include, but are not limited to, checking out books, using electronic resources, attending workshops or course-related instruction, or consulting with a librarian. Variables accounting for students' subject areas were described in different studies as academic majors, courses of study, degrees sought, or colleges of enrollment.

Soria, Fransen, and Nackerud (2017) used students' academic college as an environmental variable when examining four outcomes. Academic engagement was measured by how frequently students reported participating in classroom activities, like asking an insightful question in class. Academic skills was measured by students' perceptions of current analytical and critical thinking skills and ability to read and comprehend academic material. Engagement in scholarship included rating the frequency in which students reported judging the value of information, ideas, actions, and conclusions based on the soundness of sources, 
methods, and reasoning (among other items). The fourth outcome was GPA. Data was gathered through student surveys and library usage data. Their results suggested students in the engineering and biology colleges had lower academic engagement compared to their peers, and students in the education college had higher academic engagement (p. 15). Students in the business college reported lower academic skills development (p. 18), while students in the engineering, biology and agriculture colleges reported a lower GPA (p. 19). No data was reported about college of enrollment for engagement in scholarship. Overall, the authors "found that students" college of enrollment mattered in terms of predicting their academic outcomes" (p. 20). Anderson and Vega Garcia (2020) analyzed students' usage of library resources and services (LRU), students' perceptions of library contribution to academic success (LCS), and cumulative GPA. The first two variables were measured through a survey of undergraduate and graduate students across nine disciplines: Agriculture \& Life Sciences; Arts \& Design; Business \& Economics; Humanities; Math \& Computer Science; Physical Science \& Engineering; Social Sciences; Interdisciplinary; and Veterinary Medicine (graduate program only). They found that across all of the disciplines, if students believed the library contributed to their success, they tended to use library resources more (p. 476). Undergraduate students studying Physical Sciences \& Engineering had the largest difference, about $150 \%$ higher LCS than library usage would predict, and Business \& Economics had the lowest, about $40 \%$ higher (p. 469). The authors also found that students who had attended a course-integrated library instruction session were "more likely to have a favorable attitude about the library's role in their success, even though their GPA may not have been similarly impacted" (p. 477). Renaud et al. (2015) examined faculty, graduate student, and undergraduate student usage of their central library, specifically book checkouts and library turnstile entrances. They found that "Architecture and law were the only two 
schools with consistently positive correlations between GPA and library use," while the School of Communication and the School of Marine and Atmospheric Science both showed a negative correlation in three of the four areas of library use (p. 369). Wong and Webb (2011) found positive associations between the number of library items that students checked out and students' GPAs at graduation, but they noted that the correlations were small to medium across majors and colleges. They found that students in the School of Business were more likely than other schools to search for e-books and e-journals (p. 369). LeMaistre et al. (2018) measured library usage solely through EZProxy logs since the institution's library collection was entirely digital. They found "significant proportional differences between library users and nonusers in terms of their age, Pell recipient status, major, academic level, enrollment status (full-time or part-time), and GPA" (p. 125). Furthermore, nursing students were the most likely to use library resources, while "students from the physical and life sciences, business, and education disciplines are underrepresented among library users" (p. 136). Allison (2015) analyzed proxy logs (e-resources) and checkouts (print) to determine the academic impact of libraries on GPA for undergraduate and graduate students. Allison found that undergraduates in "humanities fields demonstrated the strongest relationship between improved grades and library use. There was a weaker, but positive, relationship for [undergraduates in] STEM and social science fields" (p. 36). It was unclear from the article whether business fields were assigned to the social sciences group. Cherry et al. (2013) examined EZProxy logins - both on-campus and off-campus - to measure impact of library usage on students' GPA. They found weak correlations between the number of logins and the overall GPA in six of the university's eight schools, including the business school. Samson (2014) examined e-resource use compared with GPA to correlate library usage and student success. Business administration students (both graduate and undergraduate) had the fourth 
lowest e-resource usage among nine schools/colleges analyzed (p. 624). The results of the study were shared with liaison librarians to inform decisions about instruction, outreach, and collections. Jara et al. (2017) analyzed undergraduate students' usage of library materials through loans and renewals of print materials and EZproxy logins to access digital materials, aiming to understand differences across academic disciplines. They found that natural sciences $(83.4 \%)$ and humanities $(82.9 \%)$ had the highest percentage of students who had borrowed print materials; social sciences had the lowest (65.1\%). Medical and health sciences fields had the highest percentage of students who accessed digital materials (43.5\%); science and technology fields had the lowest (11.8\%) (Table 4, p. 603). Moreover, they examined the relationship between using resources in the two formats, finding that "Students from the humanities, social sciences, and science and technology disciplines tended to borrow a higher number of print materials if they had accessed digital resources" (p. 611). They concluded that using digital resources were complementary to using print collections, rather than a replacement for using them (p. 613). Çetin and Howard (2016) examined how borrowing print books affected undergraduate students' academic achievements, using book circulation data and grade point averages for their analysis. They found a positive correlation between the number of books borrowed and level of academic achievement in all fields of study, with higher correlations for students studying in the Arts and Sciences faculty and for students in qualitative fields like English Language \& Literature, Political Science, Psychology, etc., compared with quantitative ones like Chemistry, Industrial Engineering, Banking \& Finance, etc. (p. 386).

Even when academic major is listed as a demographic variable collected, studies do not always report findings about differences among the majors (Gaha et al., 2018; Kot \& Jones, 2015; Soria et al., 2013; Soria \& Fransen, 2017; Stemmer \& Mahan, 2015; Thorpe, et 
al., 2016). It is unclear from the literature whether tests failed to show statistically significant differences or whether the authors were uninterested in exploring that topic. Catalano and Phillips (2016), in an investigation of the impact of library instruction on information literacy skills, drew survey participants from 13 undergraduate majors, but the sample sizes were uneven and the authors were unable to make a reliable comparison among disciplines (p. 8). Another study, by Mayer et al. (2020), specifically excluded major in their quantitative analysis for fear that lower enrollment majors would create unstable estimates and potentially make participants identifiable to investigators (p. 382).

A smaller group of articles examine preferences concerning usage of library resources by students in different academic majors. These studies have often examined electronic versus print books. Cummings et al. (2015) surveyed students across the institution about their preferences between print and e-book formats. They found that students in the arts more strongly preferred print, and that all students who preferred e-books were graduate students. Carroll et al. (2016) surveyed undergraduate student, graduate student, faculty, and staff to discern whether users preferred using electronic or print books for academic purposes, including whether type of material (monographs, edited collections, conference proceedings, etc.) affected preference. The study grouped subject disciplines into STEM and non-STEM respondents (the latter including participants from the colleges of Arts and Humanities, Behavioral and Social Sciences, and Education). They found that non-STEM respondents "showed a slight inclination for print, while STEM respondents showed a slightly larger inclination for electronic" but that "neither result was definitive enough to generate a clear guide for purchasing these formats” (p. 149). Mizrachi (2015) studied undergraduate students' academic reading format preferences and behaviors. Her analysis showed no association between undergraduates' academic reading format preferences and behaviors and 
their major - or with their age, GPA, or year of study (p. 307). Ebijuwa and Mabawonku (2019) found no significant relationship between academic discipline and use of electronic library resources among undergraduates.

Lastly, one article asked students in different subject areas to self-assess their information literacy skills in addition to gauging their attitudes about information competencies (Pinto \& Sales, 2015). Participants were grouped into five branches of knowledge based on the degrees they sought: Arts and Humanities; Social Sciences and Law; Sciences; Health Sciences; and Architecture and Engineering (p. 207). Two groups, Arts and Humanities and Social Sciences and Law, assessed themselves as most competent in the four areas studied (searching, evaluation, processing, and communication-dissemination), followed by Sciences and Architecture and Engineering. Health Sciences had the lowest scores on the information competencies, and they also needed the most improvement in their attitudes toward information literacy (p. 213). Pinto and Sales argued these results show that information literacy is discipline-dependent with "plenty of attitudinal differences between disciplines" (p. 213).

In summary, while differences among major field of study have been explored with respect to library use, academic outcomes, preferences for print versus electronic materials, and attitudes toward information competencies, we found no studies concerning student perceptions of academic librarians that disaggregated data by major field of study or gender.

\section{Materials and methods}

This study used an online survey in Qualtrics to collect data from undergraduate students at James Madison University $(n=19,665)$ in fall 2017. The IRB-approved instrument was adapted from earlier surveys by Hernon and Pastine (1977) and Fagan (2003) to collect 
both quantitative and qualitative data through a mix of closed and open-ended questions (See Appendix).

To support a balanced survey pool, liaison librarians at James Madison University (JMU) identified 55 courses to target (from 100 level to 400 level in each college) and invited faculty teaching those courses to distribute the survey to students. Some faculty provided extra credit, tracked through a separate form. In addition to this targeted pool, the survey was distributed to all undergraduates via mass email. The survey remained open for five weeks. Students who participated and provided their email address in a separate survey were eligible for a prize drawing (10 campus dining vouchers, each worth \$11). Quantitative data from the survey were analyzed using SPSS versions 23 and 26. We used an alpha level of .05 for all statistical tests. When no significant differences were found, we explored our sample's data for proportionally large differences using residuals and mean differences to illuminate questions to explore in local practice or to inform future research.

Qualitative data were coded using NVivo software version 12. Two researchers independently coded all responses to open-ended questions, then jointly reviewed references in a Not Coded Elsewhere (NCE) node for each question to ensure the response didn't fit into an existing category. The NVivo coding comparison showed $92 \%$ agreement on coded references. Because the number of coded references occasionally diverged, we used the average between the two.

\section{Results}

\section{Analysis by Gender Identity}

Survey participants were asked to choose among five gender identity options in response to the prompt, "I identify as ...": "Female," "Genderqueer or gender fluid," "Male," 
"Other" with optional text entry, and "Prefer not to say." Inspired by the challenge to explore data by gender identity (Criado Perez, 2019), the researchers conducted chi-square tests on males ( $n=94)$ versus females $(n=315)$ by Q11-Q14 but no evidence was found of a relationship between these responses and these questions. ANOVAs were conducted on 16 questions from sets Q10 and Q22 that the researchers hypothesized might have the most relationship to gender identity, but again, no significant differences were found between these groups. Chi-squares were conducted on two of the coded qualitative questions (Q16 and Q17) and male versus female, and no evidence was found of a relationship. The data for these analyses can be found in a supplementary document in the JMU institutional repository. Fourteen respondents identified in the survey as either "Genderqueer or gender fluid" $(n=4)$, "Other" $(n=6)$, or "Prefer not to say" $(n=4)$. Two of the "Other" responses entered text referring to joke memes about gender identity. The eight qualitative responses for those responding "Genderqueer or gender fluid" and "Other" (with either blank or non-joke text entry) were examined manually; they were relatively short. The groups were too small to support comparisons on the quantitative questions, and we decided to set them aside (see Discussion section for more thoughts on this).

\section{Analysis by Subject Area}

To facilitate analysis, a Subject Area variable was created with four values: Arts, Humanities, and Social Sciences (AH+SS) combined students majoring in subject areas within JMU's College of Arts and Letters and the College of Visual and Performing Arts; the College of Business (BUS) represented itself; Health and Education (HLTH+ED) combined students majoring in subjects areas in the College of Health and Behavioral Studies and the College of Education; and Science, Technology, Engineering, and Math (STEM) combined majors from the College of Science and Mathematics and the College of Integrated Science 
and Engineering. Table 1 shows which academic majors fall in each group. Seven undeclared majors responded and these were treated as missing for the remainder of analyses. Thus, the sample for this study was the 445 students who had chosen a College.

Table 1. Subject Areas that fall into each group at James Madison University.

\begin{tabular}{|c|c|c|c|}
\hline $\begin{array}{c}\text { Arts, Humanities + } \\
\text { Social Sciences } \\
\text { (AH + SS) }\end{array}$ & Business (BUS) & $\begin{array}{c}\text { Health Sciences + } \\
\text { Education } \\
\text { (HLTH + ED) }\end{array}$ & $\begin{array}{c}\text { Science, Technology, } \\
\text { Engineering \& Math } \\
\text { (STEM) }\end{array}$ \\
\hline Anthropology & Accounting & Athletic Training & Biology \\
\hline Architectural Design & $\begin{array}{l}\text { Computer } \\
\text { Information Systems }\end{array}$ & \begin{tabular}{|l|} 
Communication \\
Sciences and Disorders
\end{tabular} & Biophysical Chemistry \\
\hline Art History & Economics & Dietetics & Biotechnology \\
\hline Communication Studies & Finance & Health Sciences & Chemistry \\
\hline Dance & \begin{tabular}{|l|} 
Hospitality \\
Management
\end{tabular} & $\begin{array}{l}\text { Health Services } \\
\text { Administration } \\
\end{array}$ & Computer Science \\
\hline English & \begin{tabular}{|l|} 
International \\
Business
\end{tabular} & $\begin{array}{l}\text { Inclusive Early } \\
\text { Childhood Education }\end{array}$ & Earth Science \\
\hline Graphic Design & Management & Middle Education & Engineering \\
\hline History & Marketing & Kinesiology & Geographic Science \\
\hline Industrial Design & Quantitative Finance & Nursing & Geology \\
\hline International Affairs & $\begin{array}{l}\text { Sport and Recreation } \\
\text { Management }\end{array}$ & Psychology & $\begin{array}{l}\text { Integrated Science and } \\
\text { Technology }\end{array}$ \\
\hline Jazz Studies & & Social Work & Intelligence Analysis \\
\hline Justice Studies & & & Mathematics \\
\hline Media Arts and Design & & & Physics \\
\hline $\begin{array}{l}\text { Modern Foreign } \\
\text { Languages }\end{array}$ & & & Statistics \\
\hline \multicolumn{4}{|l|}{ Music Composition } \\
\hline \multicolumn{4}{|l|}{ Music Education } \\
\hline \multicolumn{4}{|l|}{ Music Performance } \\
\hline \multicolumn{4}{|l|}{ Music } \\
\hline \multicolumn{4}{|l|}{ Musical Theatre } \\
\hline \multicolumn{4}{|l|}{ Philosophy and Religion } \\
\hline \multicolumn{4}{|l|}{ Philosophy } \\
\hline \multicolumn{4}{|l|}{ Political Science } \\
\hline \multicolumn{4}{|l|}{$\begin{array}{l}\text { Public Policy and } \\
\text { Administration }\end{array}$} \\
\hline \multicolumn{4}{|l|}{ Sociology } \\
\hline \multicolumn{4}{|l|}{ Studio Art } \\
\hline \multicolumn{4}{|l|}{ Theatre } \\
\hline $\begin{array}{l}\text { Writing, Rhetoric \& } \\
\text { Technical } \\
\text { Communication }\end{array}$ & & & \\
\hline
\end{tabular}




\section{Demographics}

The proportions of the sample's Subject Areas were compared with the proportions in JMU's population. ${ }^{1}$ For these comparisons, we were forced to set aside the 22 student respondents who chose "College of Education," because JMU's institutional data doesn't track undergraduates pursuing Education as a field of study as falling within the College. The sample had a higher proportion of women (19\% more women than expected) and seniors (11\% more), and a lower proportion of first-year students (13\% fewer). The sample also overrepresents students in the College of Health and Behavioral Studies (15\%), and underrepresents students from STEM (-10\%) and AH+SS (-7\%).

While the research questions for this study do not involve year, and gender was found to be nonsignificant, we compared these variables' distributions across the Subject Areas to further investigate the extent to which the breakdown was representative of the JMU population. Looking at deviations in distribution of year within each Subject Area between the JMU population and the 411 students who chose a college (other than Education), we can see that in ARTS+SS, Seniors were underrepresented (10\% less than expected) and Sophomores were overrepresented (9\% more than expected). Within BUS, first-years were notably underrepresented (-17\%) and Juniors were overrepresented (14\%). Seniors in HLTH were very overrepresented (33\%) and first-years were very underrepresented (-16\%). These findings make sense given that we had extended invitations through librarian liaisons' contacts with major-intensive and capstone courses, and three longer-tenured librarians were serving health and behavioral studies departments at the time. However, they also reveal a

\footnotetext{
${ }^{1}$ For a college-by-college demographic comparison, see (Fagan et al., 2021c).
} 
strong skew in our sample of HLTH Seniors, who might be somewhat better informed about librarians than our sample's students in other colleges.

Since JMU data only provided numbers for male and female genders, we broke down Subject Area by male $(n=94)$ versus female $(n=315)$. In keeping with the overall findings of female overrepresentation of our sample, we found our sample's STEM group is particularly female-overrepresented ( $36 \%$ more than would be expected in JMU's population), followed by ARTS+SS (21\% more), BUS (14\% more), and HLTH (9\% more).

\section{Consultation of librarians in public, school, and college libraries}

Between 443 and 445 students who chose a Subject Area answered the items "How often have you consulted librarians in a public library" (Q4). Response options were 1=More than once a month, $2=$ About once a month, $3=$ Several times per year, $4=$ Less than once per year, $5=$ Never. There was no Not Sure option on this question. Descriptive statistics are provided in Table 2. While a MANOVA revealed no significant differences between college groups on how frequently they consulted with public librarians (Using Pillai's Trace, $V=0.02$, $F(9,1317)=0.83, p=0.59)$, Business students were the most likely to answer "Never" for each grade range (see Figure 1).

Table 2. How often have you consulted librarians in a public library? (Q4).

\begin{tabular}{llccc}
\hline & Subject Area & $\boldsymbol{M}$ & $\boldsymbol{s d}$ & $\boldsymbol{N}$ \\
\hline During elementary school (K-5) & AH+SS & 2.86 & 1.42 & 73 \\
\cline { 2 - 5 } & BUS & 3.32 & 1.51 & 119 \\
\cline { 2 - 5 } & HLTH+ED & 3.00 & 1.44 & 209 \\
\cline { 2 - 5 } & STEM & 2.93 & 1.64 & 42 \\
\cline { 2 - 5 } & Total & 3.06 & $\mathbf{1 . 4 8}$ & $\mathbf{4 4 3}$ \\
\hline During middle school (6-8) & AH+SS & 3.26 & 1.38 & 73 \\
& BUS & 3.60 & 1.32 & 119 \\
\cline { 2 - 5 } & HLTH+ED & 3.39 & 1.32 & 209 \\
\cline { 2 - 5 } & STEM & 3.38 & 1.21 & 42 \\
\cline { 2 - 5 } & Total & $\mathbf{3 . 4 2}$ & $\mathbf{1 . 3 2}$ & $\mathbf{4 4 3}$ \\
\hline
\end{tabular}




\begin{tabular}{lllcc}
\hline During high school (9-12) & AH+SS & 3.70 & 1.13 & 73 \\
& BUS & 3.79 & 1.18 & 119 \\
\cline { 2 - 5 } & HLTH+ED & 3.64 & 1.26 & 209 \\
\cline { 2 - 5 } & STEM & 3.64 & 1.08 & 42 \\
\cline { 2 - 5 } & Total & $\mathbf{3 . 6 9}$ & $\mathbf{1 . 2 0}$ & $\mathbf{4 4 3}$ \\
\hline
\end{tabular}

Note: Response options were 1=More than once a month, 2=About once a month, $3=$ Several times per year, $4=$ Less than once per year, $5=$ Never.

Figure 1. Percentage of students responding "Never" having consulted librarians in a public library, by Subject Area (Q4).

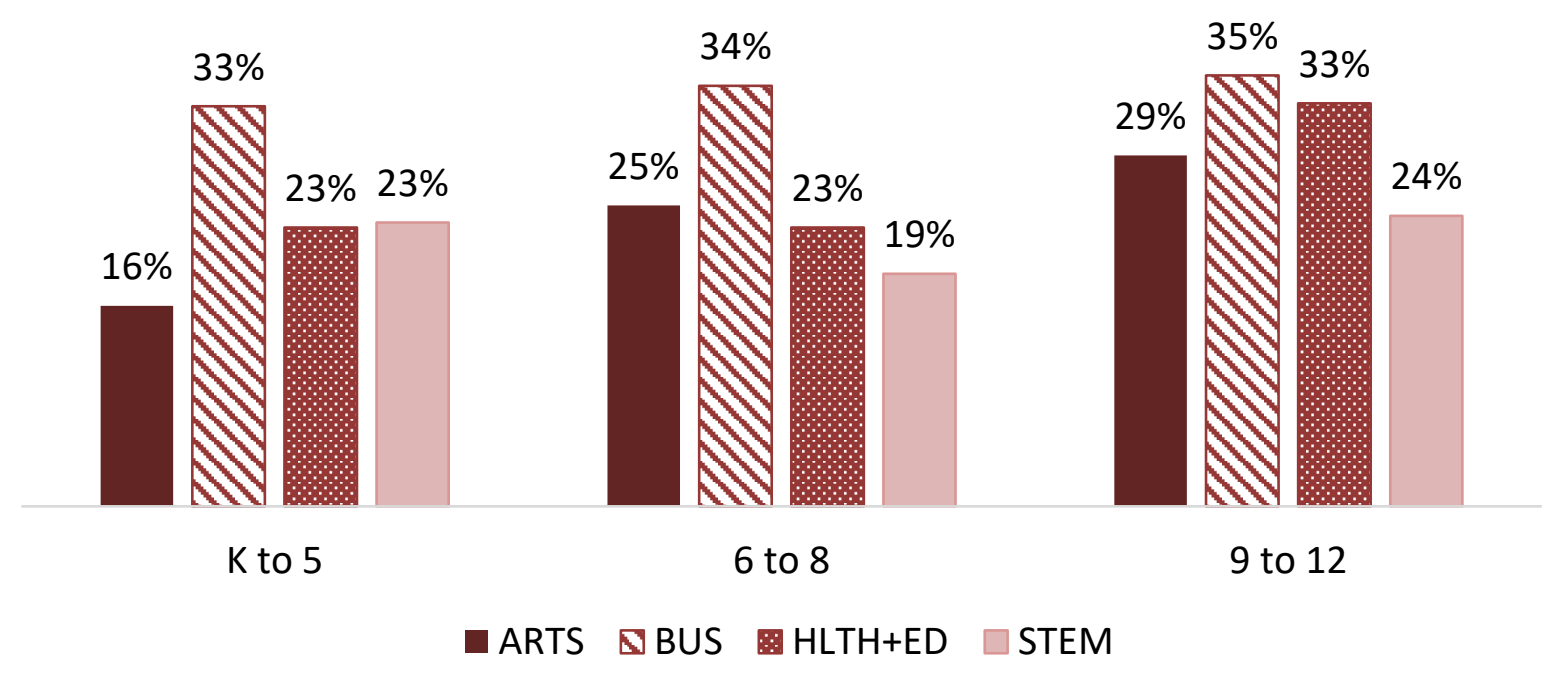

Between 441 and 442 students who chose a Subject Area answered the items, "How often did you consult your school's librarian?” (Q5, see Table 3). Response options were $1=$ More than once a month, $2=$ About once a month, $3=$ Several times per year, $4=$ Less than once per year, 5=Never, and 6, “My school didn't have a librarian.” After removing those who responded "My school didn't have a librarian," 419 cases remained for analysis. MANOVA revealed no significant differences among Subject Areas on how frequently they consulted with school librarians (Using Pillai's Trace, $V=0.02, F(9,1245)=0.82, p=0.60$ ). 
Table 3. How often did you consult your school's librarian? (Q5).

\begin{tabular}{llccc}
\hline & Subject Area & $\boldsymbol{M}$ & sd & $\boldsymbol{N}$ \\
\hline During elementary school (K-5) & AH+SS & 1.89 & 1.19 & 70 \\
& BUS & 2.29 & 1.28 & 110 \\
& HLTH+ED & 2.19 & 1.37 & 197 \\
& STEM & 1.98 & 1.22 & 42 \\
& Total & $\mathbf{2 . 1 5}$ & $\mathbf{1 . 3 0}$ & $\mathbf{4 1 9}$ \\
\hline During middle school (6-8) & AH+SS & 2.44 & 1.18 & 70 \\
& BUS & 2.77 & 1.18 & 110 \\
& HLTH+ED & 2.72 & 1.27 & 197 \\
& STEM & 2.6 & 1.31 & 42 \\
& Total & $\mathbf{2 . 6 7}$ & $\mathbf{1 . 2 3}$ & $\mathbf{4 1 9}$ \\
\hline During high school (9-12) & AH+SS & 3.06 & 1.27 & 70 \\
& BUS & 3.07 & 1.17 & 110 \\
& HLTH+ED & 3.13 & 1.27 & 197 \\
& STEM & 3.07 & 1.22 & 42 \\
& Total & $\mathbf{3 . 1}$ & $\mathbf{1 . 2 4}$ & $\mathbf{4 1 9}$ \\
\hline
\end{tabular}

Note: Response options were 1=More than once a month, 2=About once a month, 3=Several times per year, 4=Less than once per year, 5=Never. A sixth response, My school didn't have a librarian, was not included in the mean.

Table 4. To what extent, if any, do you think librarians helped you succeed? (Q6).

\begin{tabular}{llccc}
\hline & Subject Area & $\boldsymbol{M}$ & sd & $\boldsymbol{N}$ \\
\hline During elementary school (K-5) & AH+SS & 2.33 & 1.31 & 66 \\
& BUS & 2.75 & 1.30 & 111 \\
& HLTH+ED & 2.81 & 1.39 & 196 \\
& STEM & 2.69 & 1.24 & 36 \\
& Total & $\mathbf{2 . 7 1}$ & $\mathbf{1 . 3 5}$ & $\mathbf{4 0 9}$ \\
\hline During middle school (6-8) & AH+SS & 3.2 & 1.32 & 66 \\
& BUS & 3.38 & 1.11 & 111 \\
& HLTH+ED & 3.3 & 1.27 & 196 \\
& STEM & 3.39 & 1.02 & 36 \\
& Total & $\mathbf{3 . 3 1}$ & $\mathbf{1 . 2 2}$ & $\mathbf{4 0 9}$ \\
\hline During high school (9-12) & AH+SS & 3.55 & 1.34 & 66 \\
& BUS & 3.54 & 1.27 & 111 \\
& HLTH+ED & 3.41 & 1.40 & 196 \\
& STEM & 3.58 & 1.08 & 36 \\
& Total & $\mathbf{3 . 4 8}$ & $\mathbf{1 . 3 3}$ & $\mathbf{4 0 9}$ \\
\hline
\end{tabular}

Note: Response options were 1=A great deal, 2=A lot, 3=A moderate amount, 4=A little, and 5=None at all. The response 6 denoted Not sure but was not included in the analysis.

Four hundred and nine students who chose a Subject Area answered the item, "To what extent, if any, do you think librarians helped you succeed?...” (Q6). Response options 
included 1=A great deal, 2=A lot, 3=A moderate amount, 4=A little, and 5=None at all. The response 6 denoted Not sure but was not included in the analysis. MANOVA revealed no significant differences between groups on to what extent they thought librarians helped them succeed in school (Using Pillai's Trace, $V=0.02, F(9,1215)=1.10, p=0.36)$ (See Table 4).

A total of 444 students who chose a Subject Area responded to "How often have you consulted an academic librarian during your college education?” (Q8, see Table 5). Response options were $1=$ More than once a month, $2=$ About once a month, $3=$ Several times per year, 4=Less than once per year, and 5, Never. There was no Not Sure option on this question. While no significant differences were observed between groups for how often they consulted with librarians during their college years, $F(3,440)=1.56, p=0.20$, an ANOVA showed a significant difference between groups' perceptions of whether librarians helped them succeed in college in answer to the question, "To what extent, if any, do you think librarians helped you succeed during your college education?”, $F(369,3)=2.99, p=.03$. Response options were 1=A great deal, $2=\mathrm{A}$ lot, $3=\mathrm{A}$ moderate amount, $4=\mathrm{A}$ little, and 5=None at all. The response 6 denoted Not sure but was not included in the analysis. A post hoc comparison with Tukey HSD was significant $(p=.04)$ and showed that AH+SS students $(M=3.29, s d=1.40)$ were more likely to perceive librarians helped them succeed during their college career than STEM students $(M=4.03, s d=1.14)$, with a Cohen's effect size of 0.58 (medium). AH+SS students' responses were closer to 3, denoting “A moderate amount," compared with STEM's, which were close to 4 "A little."

Looking for trends to inform future research questions, ARTS+SS students $(M=3.29$, $s d=1.40)$ also were more likely than BUS $(M=3.74, s d=1.31)$ or HLTH+ED students $(M=3.78, s d=1.26)$ to perceive librarians helped them succeed during college. 
Four hundred and thirty-nine students who chose a Subject Area answered the questions "How much do you think an entry-level JMU librarian makes per year?" (Q15) and "What do you think is the minimum level of educational qualifications required to be hired as an entry-level JMU librarian?" (Q20). ANOVA showed no significant differences between Subject Areas in perceptions of entry-level salaries, $F(3,434)=0.97, p=0.41$, or degrees $F(3,435)=1.38, p=0.25)($ See Table 6).

Table 5. Questions concerning academic librarians during the college years? (Q7 and Q8).

\begin{tabular}{lcccccc}
\hline $\begin{array}{c}\text { How often have you consulted an academic } \\
\text { librarian during your college years? }\end{array}$ & \multicolumn{3}{c}{$\begin{array}{c}\text { To what extent, if any, do you think } \\
\text { librarians } \begin{array}{c}\text { helped you succeed during your } \\
\text { college education? }\end{array}\end{array}$} \\
\hline Subject Area & $\boldsymbol{M}$ & $\boldsymbol{s \boldsymbol { d }}$ & $\boldsymbol{N}$ & $\boldsymbol{M}$ & $\boldsymbol{s d}$ & $\boldsymbol{N}$ \\
\hline AH+SS & 3.82 & 1.22 & 73 & 3.29 & 1.40 & 59 \\
BUS & 4.03 & 1.06 & 119 & 3.74 & 1.31 & 102 \\
HLTH+ED & 4.10 & 1.05 & 209 & 3.78 & 1.26 & 178 \\
STEM & 4.21 & 0.94 & 43 & 4.03 & 1.14 & 34 \\
Total & $\mathbf{4 . 0 5}$ & $\mathbf{1 . 0 7}$ & $\mathbf{4 4 4}$ & $\mathbf{3 . 7 1}$ & $\mathbf{1 . 3}$ & $\mathbf{3 7 3}$ \\
\hline
\end{tabular}

Note: Response options on "consulted" were 1=More than once a month, 2=About once a month, $3=$ Several times per year, 4=Less than once per year, and 5, Never. There was no Not Sure option on this question. Response options on "succeed" were 1=A great deal, 2=A lot, 3=A moderate amount, 4=A little, 5=None at all.

Table 6. "How much do you think an entry-level James Madison University librarian makes per year?" and "What do you think is the minimum level of educational qualifications required to be hired as an entry-level James Madison University librarian?" (Q15 and Q20).

\begin{tabular}{lcccccc}
\hline Subject Area & $\boldsymbol{M}$ & $\begin{array}{c}\text { Salaries } \\
\text { sd }\end{array}$ & $\boldsymbol{N}$ & $\boldsymbol{M}$ & Degrees & $\boldsymbol{N}$ \\
\hline AH+SS & 3.03 & 1.36 & 71 & 2.87 & 0.88 & 71 \\
BUS & 3.24 & 1.39 & 119 & 2.68 & 0.99 & 119 \\
HLTH+ED & 3.29 & 1.24 & 205 & 2.77 & 0.96 & 206 \\
STEM & 3.42 & 1.52 & 43 & 3.00 & 1.07 & 43 \\
Total & 3.25 & 1.33 & 438 & 2.79 & 0.97 & 439 \\
\hline
\end{tabular}

Note: "Degrees" ranged from 1=High school degree to 7=Multiple doctoral degrees, with 3 denoting Bachelor's degree. "Salaries" ranged from 1=Less than $\$ 20,000$ to $8=$ More than $\$ 80,000$, with 3 denoting $\$ 30,000-\$ 39,999$. 
Chi-square tests for independence were conducted to look for associations between

Subject Area and the major coding categories (Expertise, Interpersonal Skills, Organization,

Resources, and Teaching \& Pedagogy) that emerged from these two ${ }^{2}$ questions:

- "What skills do you think librarians have that are valuable to you?" (Q16, n=329)

- "What skills do you think librarians have that are valuable to the university?" (Q17, $n=296)$.

Example responses for these questions are found in Table 7.

Table 7. Definitions for coding "What skills do you think librarians have..." (Q16, n=329; Q17, $n=296)$.

\begin{tabular}{|c|c|c|}
\hline Major category & Description & Example responses (Q16 \& Q17) \\
\hline Expertise & $\begin{array}{l}\text { Skills in finding information and using it, possibly } \\
\text { as part of a formal research process. }\end{array}$ & $\begin{array}{l}\text { "Helping find books" } \\
\text { "Librarians are extremely } \\
\text { knowledgeable in doing academic } \\
\text { research, and in the correct } \\
\text { techniques used to find } \\
\text { appropriate and relevant research } \\
\text { articles/sources" }\end{array}$ \\
\hline $\begin{array}{l}\text { Interpersonal } \\
\text { Skills }\end{array}$ & $\begin{array}{l}\text { Communication skills, customer service skills, } \\
\text { social skills, or personal qualities such as } \\
\text { "patient" or "intelligent" }\end{array}$ & $\begin{array}{l}\text { "People skills" } \\
\text { "They are helpful and kind" }\end{array}$ \\
\hline $\begin{array}{l}\text { Library Facilities / } \\
\text { Library as Place }\end{array}$ & About the library as a building, as a place & $\begin{array}{l}\text { "Maintaining the library as an area } \\
\text { for people to get work done" } \\
\text { "Knowledge of the facility" }\end{array}$ \\
\hline Organization & $\begin{array}{l}\text { Arranging items logically (e.g., classification } \\
\text { systems) or the skills and knowledge required to } \\
\text { carry out these tasks }\end{array}$ & $\begin{array}{l}\text { "Organization of books" } \\
\text { "Dewey decimal system" }\end{array}$ \\
\hline Resources & $\begin{array}{l}\text { Materials generically (holdings, resources, stuff, } \\
\text { etc.) or specifically (data, articles, books, films, } \\
\text { etc.); collection management. Often also coded } \\
\text { as expertise in locating/accessing information }\end{array}$ & $\begin{array}{l}\text { "Book knowledge" } \\
\text { "Knowledge of scholarly resources" }\end{array}$ \\
\hline $\begin{array}{l}\text { Teaching \& } \\
\text { Pedagogy }\end{array}$ & $\begin{array}{l}\text { Teaching and instruction for individuals and } \\
\text { groups, as well as mentions of student learning } \\
\text { or pedagogical practices; also includes } \\
\text { assistance provided to improve others' teaching }\end{array}$ & $\begin{array}{l}\text { "Being able to teach" } \\
\text { "Teach skills on how to use the } \\
\text { library" }\end{array}$ \\
\hline
\end{tabular}

${ }^{2}$ Readers of our other articles might recall a third question in this set, "What do you think academic librarians learn in their library classes? Please write at least three topics you think are covered in library school classes." Prior analysis (Fagan et al., 2021c) showed this question provided little new information, so we did not include it in this study. 
No evidence was found for an association between subject areas and skills valuable to students $\left.X^{2}(12, N=649)=9.22, \mathrm{p}=0.68\right)$; nor for skills valuable to the university $X^{2}(12$, $N=500)=11.68, \mathrm{p}=0.47)$. Despite the lack of significance, we explored differences by Subject Area on questions 16 and 17 for trends that might provide support for future research.

Three hundred and twenty-nine students who chose a Subject Area responded to the question, "What skills do you think librarians have that are valuable to you?" (Q16) for a total of 649 coded references. Across the Subject Areas, HLTH+ED had the most respondents (142), followed by BUS (94), AH+SS (62), and STEM (31). Expertise was the category most frequently mentioned among all four Subject Areas (57\% for BUS and STEM; $56 \%$ for $\mathrm{AH}+\mathrm{SS}$ and HLTH+ED) as shown in Figure 2. Resources were mentioned second most often by all groups (HLTH+ED, 22\%; AH+SS, 20\%; BUS, 19\%; STEM, 17\%). Interpersonal Skills were mentioned third most often, though BUS and STEM had more mentions compared to the other two (both at 17\%, compared to $11 \%$ for the other two).

There is more variation observed when examining the types of Expertise each Subject Area mentioned as valuable to them ( $n=237 ; 364$ coded references). Example responses to illustrate types of Expertise are provided in Table 8. Librarians' skills with Research was most valuable to BUS (42\% of this Subject Area's Expertise mentions), AH+SS (40\%) and HLTH+ED (33\%). STEM students ranked Research (21\%) behind another type of Expertise, Locating \& Accessing Information (31\%). See Figure 3. HLTH+ED and BUS ranked Locating \& Accessing Information as the second most valuable to them $(30 \%$ and $21 \%$, respectively), with $\mathrm{AH}+\mathrm{SS}$ ranking it third (20\%) behind General-Library Related Knowledge (23\%). General-Library Related Knowledge ranked third most valuable to the other subject areas (BUS at 19\%, HLTH+ED at 14\%, and STEM at14\%). 
Figure 2. "What skills do you think librarians have that are valuable to you?" (Q16, n=329, 649 coded references).

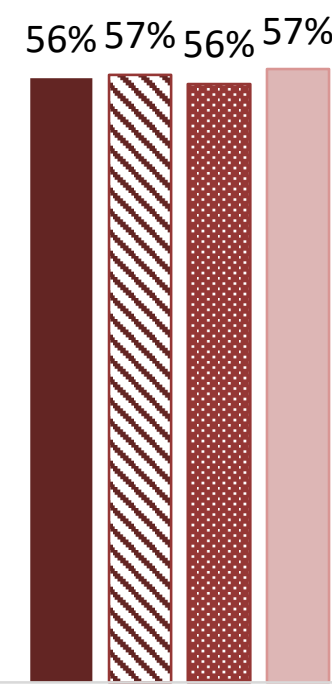

Expertise

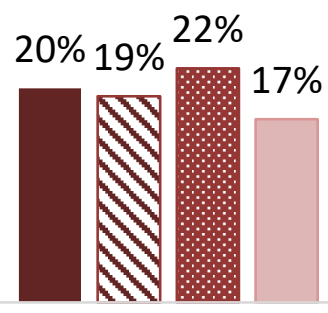

Resources

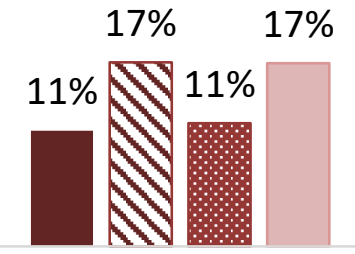

Interpersonal Skills

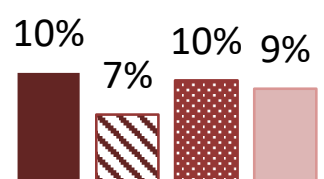

Organization $\begin{array}{llll}1 \% & 1 \% & 0 \%\end{array}$

Teaching \& Pedagogy

aH+SS $\triangle B$ BUS HLTH+ED $\square$ STEM 
Table 8. Definitions for coding of sub-categories of Expertise in "What skills do you think librarians have..." (Q16) and Why do you like to ask ..." (Q17).

\begin{tabular}{|l|l|l|}
\hline Subcategory & Description & Example responses (Q16 \& Q17) \\
\hline $\begin{array}{l}\text { General Library- } \\
\text { Related Knowledge }\end{array}$ & Librarians "knowing stuff" & $\begin{array}{l}\text { "Library knowledge" } \\
\text { "Extensive knowledge" }\end{array}$ \\
\hline $\begin{array}{l}\text { Locating \& Accessing } \\
\text { Information }\end{array}$ & $\begin{array}{l}\text { Furnishing or finding needed } \\
\text { information; usually also coded with a } \\
\text { particular type of resource (databases, } \\
\text { books, articles, data, etc.) }\end{array}$ & $\begin{array}{l}\text { "How to find books" } \\
\text { "They can help me find the } \\
\text { information I need" }\end{array}$ \\
\hline Research & $\begin{array}{l}\text { Research as either a noun, adjective or } \\
\text { a verb; usually focused on processes }\end{array}$ & $\begin{array}{l}\text { "Research skills" } \\
\text { "How to do proper research" }\end{array}$ \\
\hline Technology & $\begin{array}{l}\text { Computers, software, or technology } \\
\text { management skills }\end{array}$ & $\begin{array}{l}\text { "Can help students with technology" } \\
\text { "Technology skills" }\end{array}$ \\
\hline All Other Expertise & $\begin{array}{l}\text { Skills that didn't fall into one of the } \\
\text { other sub-categories, such as } \\
\text { librarians' knowledge of using } \\
\text { information ethically, evaluating } \\
\text { information, and preserving } \\
\text { information, etc. }\end{array}$ & "Citing/bibliographies" \\
\hline \multicolumn{2}{|l}{} & "Knowledge of invalid resources" \\
\hline
\end{tabular}

When it comes to librarians' skill with Resources, participants $(n=84 ; 91.5$ coded references) mentioned books most frequently by a sizable margin across all four Subject Areas: $81 \%$ among BUS, $70 \%$ among $\mathrm{AH}+\mathrm{SS}, 67 \%$ among STEM, and 64\% among HLTH+ED. (See Figure 4). AH+SS and HLTH+ED mentioned Databases second most frequently among Resources (both at 22\%), though BUS and STEM were not far behind (19\% and 17\%, respectively). STEM students mentioned Articles \& Journals in those words as often as Databases (17\%), more often than HLTH+ED (12\%), AH+SS (7\%) and BUS (zero mentions). Lastly, one HLTH+ED participant specifically called out Data as a Resource in which librarians' skills were valuable. Participants in the other Subject Areas did not mention Data as a Resource. 
Figure 3. "What skills do you think librarians have that are valuable to you?" (Q16 broken down by Expertise, $n=237,364$ coded references).

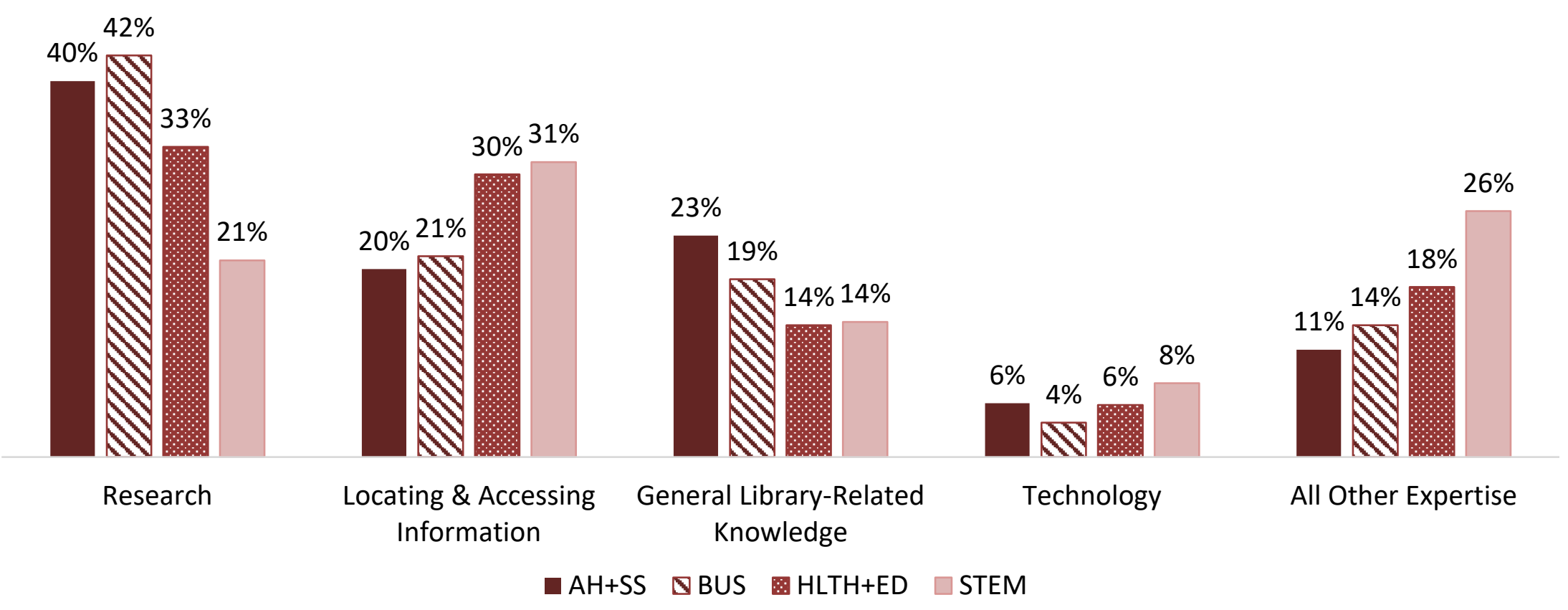


Figure 4. “What skills do you think librarians have that are valuable to you?" (Q16 broken down by Resources, $n=84 ; 91.5$ coded references).

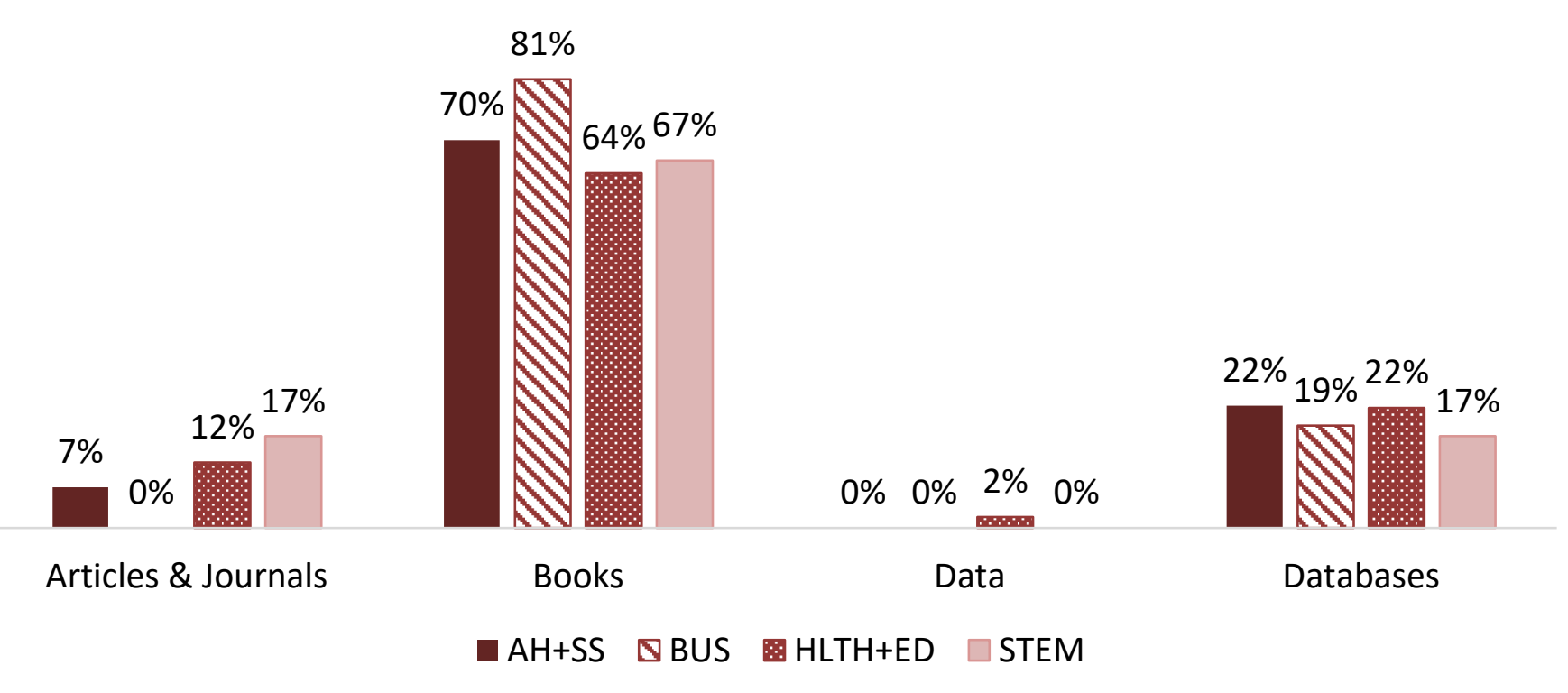


Two hundred and ninety-six students who chose a Subject Area responded to the question "What skills do you think librarians have that are valuable to the university?" (Q17) for a total of 523.5 coded references. Across the Subject Areas, HLTH+ED had the most respondents (127), followed by BUS (88), AH+SS (52), and STEM (29). Expertise was the top-ranked category by all four groups (HLTH+ED, 54\%; AH+SS, 52\%; STEM, 49\%; BUS, $48 \%$ ) and are shown in Figure 5. Resources was the second-ranked category for three of the four groups, with the percentage of STEM students that mentioned Resources (26\%) higher than the other groups (HLTH+ED, 18\%; BUS 16\%; AH+SS,14\%). Looking at the absolute value of standardized residuals greater than 1.5 , the percentage of business students that mentioned Interpersonal Skills was higher than the expected count (standardized residual=1.6), with $17 \%$ of mentions compared to HLTH+ED (13\%), AH+SS (8\%) and STEM (6\%). Interpersonal Skills was the second-ranked category among business students; other students ranked Interpersonal Skills third (HLTH+ED), fourth (AH+SS) and fifth (STEM), respectively. Teaching \& Pedagogy ranked fifth (HLTH+ED) or sixth (all others) among all four groups. 
Figure 5. “What skills do you think librarians have that are valuable to the university?” (Q17, n=296, 523.5 coded references).

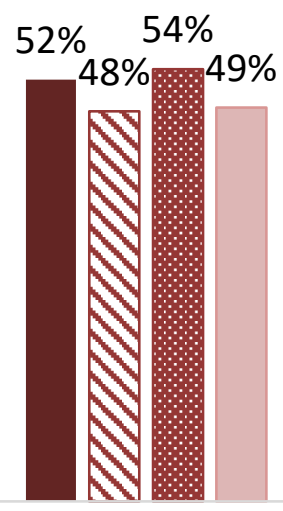

Expertise

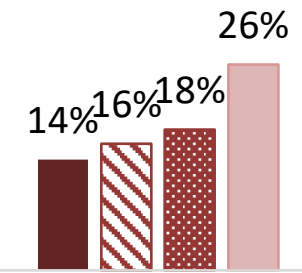

Resources

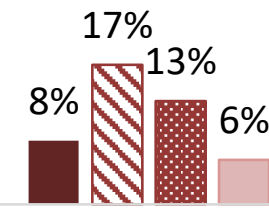

Interpersonal Skills
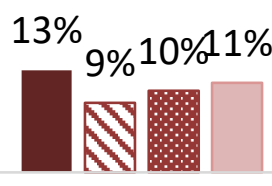

Organization

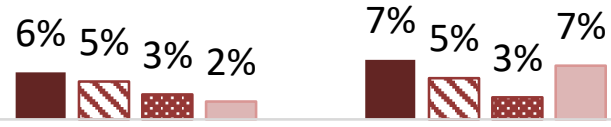

Teaching \& Pedagogy
Unspecified Help

$\square \mathrm{AH}+\mathrm{SS} \quad \triangle \mathrm{BUS} \mathrm{HLTH+ED} \square \mathrm{STEM}$ 
What Librarians Do: Duties of Librarians

Chi-square tests for independence were conducted to look for associations between subject area and responses to these questions:

- In the JMU Libraries, can you tell which workers are librarians? (Q11, n=439)

- In the JMU Libraries, do you ever ask to speak to a librarian? (Q12, $n=438)$

- Do you think academic librarians are faculty at James Madison University? (Q13, $n=439)$

- Do you think academic librarians are faculty at every university? (Q14, $n=440)$.

Response options were Yes, No, and Not Sure. See Table 9 for descriptive statistics.

No evidence was found for an association between subject areas and responses to Q11 $X^{2}$ (6, $\left.N=439)=4.53, p=0.61) ; \mathrm{Q} 12 X^{2}(6, N=438)=3.24, p=0.78\right) ; X^{2}(6, N=439)=10.14$, $p=0.12)$; or $\left.\mathrm{Q} 14 X^{2}(6, N=440)=11.20, p=0.06\right)$.

Table 9. Four items related to what librarians do (Q12-14).

In the James Madison University Libraries, can you tell which workers are librarians?

$\begin{array}{lccccc} & \text { AH+SS } & \text { BUS } & \text { HLTH+ED } & \text { STEM } & \text { Total } \\ \text { Yes } & 34 & 58 & 92 & 24 & 208 \\ \text { No } & 23 & 30 & 68 & 10 & 131 \\ \text { Not sure } & 14 & 31 & 47 & 8 & 100 \\ \text { Total } & \mathbf{7 1} & \mathbf{1 1 9} & \mathbf{2 0 7} & \mathbf{4 2} & \mathbf{4 3 9}\end{array}$

In the James Madison University Libraries, do you ever ask to speak to a librarian?

$\begin{array}{lccccc} & \text { AH+SS } & \text { BUS } & \text { HLTH+ED } & \text { STEM } & \text { Total } \\ \text { Yes } & 25 & 36 & 58 & 11 & 130 \\ \text { No } & 42 & 78 & 141 & 28 & 289 \\ \text { Not sure } & 4 & 5 & 7 & 3 & 19 \\ \text { Total } & \mathbf{7 1} & \mathbf{1 1 9} & \mathbf{2 0 6} & \mathbf{4 2} & \mathbf{4 3 8}\end{array}$

\begin{tabular}{lccccc}
\hline Do you think academic librarians are faculty at James Madison University? \\
& AH+SS & BUS & HLTH+ED & STEM & Total \\
Yes & 60 & 100 & 183 & 35 & 378 \\
No & 1 & 11 & 11 & 4 & 27 \\
Not sure & 10 & 8 & 13 & 3 & 34 \\
Total & $\mathbf{7 1}$ & $\mathbf{1 1 9}$ & $\mathbf{2 0 7}$ & $\mathbf{4 2}$ & $\mathbf{4 3 9}$ \\
\hline
\end{tabular}




\begin{tabular}{lccccc}
\hline Do you think academic librarians are faculty at every university? \\
& AH+SS & BUS & HLTH+ED & STEM & Total \\
Yes & 34 & 71 & 140 & 27 & 272 \\
No & 14 & 26 & 33 & 8 & 81 \\
Not sure & 23 & 22 & 34 & 8 & 87 \\
Total & $\mathbf{7 1}$ & $\mathbf{1 1 9}$ & $\mathbf{2 0 7}$ & $\mathbf{4 3}$ & $\mathbf{4 4 0}$ \\
\hline
\end{tabular}

Exploring the responses to inform future research, we noticed 57\% of STEM students said they could tell which workers are librarians, compared with $48 \%, 49 \%$, and $44 \%$ of $\mathrm{AH}+\mathrm{SS}$, BUS, and HLTH+ED students, respectively. Furthermore, 35\% of AH+SS students said they asked to speak to a librarian, compared to $30 \%$ of BUS, $28 \%$ of HLTH+ED, and $26 \%$ of STEM students. Regarding faculty status, AH+SS students were the least sure about whether academic librarians are faculty $-14 \%$ of $\mathrm{AH}+\mathrm{SS}$ students were not sure about JMU librarians, compared with 7\% of BUS and STEM students, and 6\% of HLTH+ED students. Furthermore, $32 \%$ of $\mathrm{AH}+\mathrm{SS}$ students were not sure about academic librarians in general, compared with 18\% (BUS), 16\% (HLTH+ED), and 19\% (STEM). Between 404-439 students who chose a Subject Area answered the items with the prompt, "How often do you think academic librarians perform the following duties?" (Q10, see Table 10). Response options were $1=$ Frequently, 2=Sometimes, 3=Rarely, and 4=Never. "Not Sure" was also an option but was not included in the analysis. ANOVAs showed significant differences with respect to Creating Subject Guides, $F(3,400)=3.78, p=.01$, Supporting library computers/printers/photocopiers $F(3,424)=2.91, p=.03$, and Providing IT support for campus wi-fi $F(3,422)=3.70, p=.01$. Post hoc comparisons using Tukey HSD were conducted to determine which pairs of College groupings differed significantly $(p<.05)$ and effect size was calculated with Cohen's $d$. BUS students $(M=1.97, S D=0.75)$ thought Creating Subject Guides was a less frequent duty than HLTH+ED students $(M=1.72, S D=0.75)$ with an effect size of 0.34 (small). For Supporting library computers/printers/photocopiers, AH+SS students 
$(M=2.30, S D=0.94)$ thought librarians did this less frequently than did BUS students

$(M=1.90, S D=.80)$ with an effect size of .46 (medium). Finally, AH+SS students $(M=2.91$, $S D=0.98$ ) perceived librarians provided IT support for campus wi-fi less frequently than HLTH+ED $(M=2.46, S D=1.02)$, with an effect size of 0.45 (medium).

There were six items with less than a .1 scale point difference between groups, underscoring the lack of variance among Subject Areas in perceptions of librarians' duties: Helping users to find books; Lending books, films and equipment to users; Evaluating student learning; Planning special events at the library; Teaching copyright principles (in classes or one-on-one); and Analyzing the effectiveness of library services and programs.

\section{What Librarians Are Like: Motivations and Affective Behaviors}

There were 445 responses for "Please drag and drop the following reasons librarians chose to become librarians $1-9$, where 1 is the top reason that librarians want to be librarians. You may write in another reason and rank it too." (see Table 11). An "Other" option with text entry was listed in addition to the nine offered nine reasons; thus, the results actually ranked items 1-10. As this was a ranked-choice question, there was no missing data other than the 7 Undeclared students removed for analysis. 
Table 10. How often do you think academic librarians perform the following duties? (Q10).

\begin{tabular}{|c|c|c|c|c|c|c|c|c|c|}
\hline & Subject Area & $M$ & $s d$ & $N$ & & Subject Area & $M$ & $s d$ & $N$ \\
\hline \multirow[t]{4}{*}{ Issuing library cards } & $\mathrm{AH}+\mathrm{SS}$ & 2.32 & 0.95 & 63 & \multirow[t]{4}{*}{ Creating online tutorials } & $\mathrm{AH}+\mathrm{SS}$ & 2.18 & 0.81 & 65 \\
\hline & BUS & 2.09 & 0.94 & 115 & & BUS & 2.17 & 0.83 & 115 \\
\hline & $\mathrm{HLTH}+\mathrm{ED}$ & 2.11 & 0.98 & 200 & & $\mathrm{HLTH}+\mathrm{ED}$ & 1.97 & 0.76 & 202 \\
\hline & STEM & 2.47 & 1.11 & 36 & & STEM & 2.10 & 0.79 & 42 \\
\hline$F(3,410)=2.17, p=0.09$ & Total & 2.17 & 0.98 & 414 & $F(3,420)=2.31, p=0.08$ & Total & 2.07 & 0.79 & 424 \\
\hline \multirow[t]{4}{*}{ Helping users to find books } & $\mathrm{AH}+\mathrm{SS}$ & 1.36 & 0.54 & 70 & \multirow[t]{4}{*}{ Repairing damaged materials } & $\mathrm{AH}+\mathrm{SS}$ & 2.25 & 0.85 & 69 \\
\hline & BUS & 1.33 & 0.56 & 117 & & BUS & 2.16 & 0.93 & 116 \\
\hline & $\mathrm{HLTH}+\mathrm{ED}$ & 1.35 & 0.60 & 208 & & HLTH+ED & 2.03 & 0.79 & 200 \\
\hline & STEM & 1.35 & 0.48 & 43 & & STEM & 2.16 & 0.84 & 43 \\
\hline$F(3,434)=0.03, p=0.99$ & Total & 1.35 & 0.56 & 438 & Welch's's $F(3,138.03)=1.45, p=0.24$ & Total & 2.11 & 0.85 & 428 \\
\hline \multirow{4}{*}{$\begin{array}{l}\text { Lending books, films and equipment } \\
\text { to users }\end{array}$} & $\mathrm{AH}+\mathrm{SS}$ & 1.34 & 0.61 & 71 & \multirow[t]{4}{*}{ Planning special events at the library } & $\mathrm{AH}+\mathrm{SS}$ & 1.99 & 0.81 & 69 \\
\hline & BUS & 1.36 & 0.63 & 118 & & BUS & 1.99 & 0.80 & 115 \\
\hline & $\mathrm{HLTH}+\mathrm{ED}$ & 1.34 & 0.57 & 206 & & $\mathrm{HLTH}+\mathrm{ED}$ & 1.99 & 0.77 & 199 \\
\hline & STEM & 1.30 & 0.46 & 43 & & STEM & 1.98 & 0.71 & 43 \\
\hline$F(3,434)=0.09, p=0.97$ & Total & 1.34 & 0.58 & 438 & $F(3,422)=0.00, p=1.00$ & Total & 1.99 & 0.77 & 426 \\
\hline \multirow[t]{4}{*}{ Processing fines } & $\mathrm{AH}+\mathrm{SS}$ & 2.03 & 0.83 & 70 & \multirow{4}{*}{$\begin{array}{l}\text { Publishing research about the library } \\
\text { profession }\end{array}$} & $\mathrm{AH}+\mathrm{SS}$ & 2.20 & 0.83 & 65 \\
\hline & BUS & 1.94 & 0.74 & 115 & & BUS & 2.17 & 0.83 & 115 \\
\hline & $\mathrm{HLTH}+\mathrm{ED}$ & 1.88 & 0.74 & 203 & & HLTH+ED & 2.04 & 0.81 & 196 \\
\hline & STEM & 2.00 & 0.78 & 40 & & STEM & 2.21 & 0.87 & 42 \\
\hline$F(3,424)=0.79, p=0.50$ & Total & 1.93 & 0.76 & 428 & $F(3,414)=1.11, p=0.35$ & Total & 2.12 & 0.82 & 418 \\
\hline \multirow[t]{4}{*}{ Giving general directional help } & $\mathrm{AH}+\mathrm{SS}$ & 1.35 & 0.59 & 71 & \multirow[t]{4}{*}{ Working in Starbucks } & $\mathrm{AH}+\mathrm{SS}$ & 3.58 & 0.63 & 66 \\
\hline & BUS & 1.27 & 0.52 & 117 & & BUS & 3.26 & 0.94 & 109 \\
\hline & HLTH+ED & 1.30 & 0.55 & 207 & & HLTH+ED & 3.45 & 0.84 & 197 \\
\hline & STEM & 1.17 & 0.38 & 42 & & STEM & 3.48 & 0.93 & 40 \\
\hline Welch's $F(3,149.26)=1.69, p=0.17$ & Total & 1.29 & 0.53 & 437 & Welch's $F(3,133.01)=2.39, p=0.07$ & Total & 3.42 & 0.85 & 412 \\
\hline \multirow{4}{*}{$\begin{array}{l}\text { Buying books, journals and electronic } \\
\text { material }\end{array}$} & $\mathrm{AH}+\mathrm{SS}$ & 1.71 & 0.70 & 70 & \multirow{4}{*}{$\begin{array}{l}\text { Supporting library } \\
\text { computers/printers/ } \\
\text { photocopiers }\end{array}$} & $\mathrm{AH}+\mathrm{SS}$ & 2.30 & 0.94 & 69 \\
\hline & BUS & 1.76 & 0.70 & 113 & & BUS & 1.90 & 0.80 & 113 \\
\hline & HLTH+ED & 1.73 & 0.75 & 204 & & HLTH+ED & 2.04 & 0.91 & 203 \\
\hline & STEM & 1.46 & 0.55 & 41 & & STEM & 2.00 & 1.00 & 43 \\
\hline$F(3,424)=1.86, p=0.14$ & Total & 1.71 & 0.72 & 428 & $F(3,424)=2.91, p=0.03$ & Total & 2.04 & 0.90 & 428 \\
\hline \multirow[t]{4}{*}{ Removing outdated books } & $\mathrm{AH}+\mathrm{SS}$ & 1.94 & 0.80 & 69 & \multirow[t]{4}{*}{ Providing IT support for campus wi-fi } & $\mathrm{AH}+\mathrm{SS}$ & 2.91 & 0.98 & 69 \\
\hline & BUS & 2.03 & 0.76 & 117 & & BUS & 2.68 & 0.99 & 112 \\
\hline & $\mathrm{HLTH}+\mathrm{ED}$ & 1.94 & 0.79 & 200 & & HLTH+ED & 2.46 & 1.03 & 204 \\
\hline & STEM & 1.83 & 0.75 & 40 & & STEM & 2.66 & 1.11 & 41 \\
\hline$F(3,422)=0.72, p=0.54$ & Total & 1.95 & 0.78 & 426 & $F(3,422)=3.70, p=0.01$ & Total & 2.61 & 1.03 & 426 \\
\hline
\end{tabular}


Table 10 (continued). How often do you think academic librarians perform the following duties? (Q10).

\begin{tabular}{|c|c|c|c|c|c|c|c|c|c|}
\hline & Subject Area & $M$ & $s d$ & $N$ & & Subject Area & $M$ & $s d$ & $N$ \\
\hline \multirow[t]{4}{*}{ Creating Subject Guides } & $\mathrm{AH}+\mathrm{SS}$ & 1.88 & 0.73 & 67 & \multirow{4}{*}{$\begin{array}{l}\text { Teaching research skills (in classes or } \\
\text { one-on-one) }\end{array}$} & $\mathrm{AH}+\mathrm{SS}$ & 1.63 & 0.68 & 71 \\
\hline & BUS & 1.97 & 0.75 & 112 & & BUS & 1.69 & 0.74 & 111 \\
\hline & HLTH+ED & 1.72 & 0.75 & 190 & & $\mathrm{HLTH}+\mathrm{ED}$ & 1.72 & 0.75 & 204 \\
\hline & STEM & 1.63 & 0.60 & 35 & & STEM & 1.60 & 0.66 & 43 \\
\hline$F(3,400)=3.78, p=0.01$ & Total & 1.81 & 0.74 & 404 & $F(3,425)=0.42, p=0.74$ & Total & 1.69 & 0.73 & 429 \\
\hline \multirow{4}{*}{$\begin{array}{l}\text { Giving general help to students for } \\
\text { research }\end{array}$} & $\mathrm{AH}+\mathrm{SS}$ & 1.39 & 0.49 & 71 & \multirow{4}{*}{$\begin{array}{l}\text { Teaching software skills (in classes or } \\
\text { one-on-one) }\end{array}$} & $\mathrm{AH}+\mathrm{SS}$ & 1.99 & 0.79 & 70 \\
\hline & BUS & 1.46 & 0.58 & 118 & & BUS & 2.07 & 0.91 & 110 \\
\hline & HLTH+ED & 1.32 & 0.53 & 207 & & HLTH+ED & 1.93 & 0.81 & 200 \\
\hline & STEM & 1.35 & 0.65 & 43 & & STEM & 2.02 & 0.84 & 42 \\
\hline \multirow{5}{*}{$\begin{array}{l}\text { Welch's } F(3,138.95)=1.59, p=0.20 \\
\text { Giving subject-specific help to } \\
\text { students for research }\end{array}$} & Total & 1.37 & 0.55 & 439 & \multirow{5}{*}{$\begin{array}{l}F(3,418)=0.72, p=0.54 \\
\text { Teaching copyright principles (in } \\
\text { classes or one-on-one) }\end{array}$} & Total & 1.99 & 0.84 & 422 \\
\hline & $\mathrm{AH}+\mathrm{SS}$ & 1.53 & 0.63 & 70 & & $\mathrm{AH}+\mathrm{SS}$ & 1.86 & 0.69 & 69 \\
\hline & BUS & 1.55 & 0.68 & 116 & & BUS & 1.79 & 0.71 & 110 \\
\hline & HLTH+ED & 1.49 & 0.65 & 207 & & HLTH+ED & 1.79 & 0.76 & 204 \\
\hline & STEM & 1.62 & 0.73 & 42 & & STEM & 1.81 & 0.80 & 42 \\
\hline \multirow{5}{*}{$\begin{array}{l}F(3,431)=0.57, p=0.64 \\
\text { Giving general help to faculty for } \\
\text { research }\end{array}$} & Total & 1.52 & 0.66 & 435 & \multirow{5}{*}{$\begin{array}{l}F(3,421)=0.13, p=0.94 \\
\text { Marketing library services and } \\
\text { programs }\end{array}$} & Total & 1.80 & 0.74 & 425 \\
\hline & $\mathrm{AH}+\mathrm{SS}$ & 1.51 & 0.56 & 70 & & $\mathrm{AH}+\mathrm{SS}$ & 1.94 & 0.74 & 70 \\
\hline & BUS & 1.59 & 0.70 & 117 & & BUS & 1.81 & 0.74 & 114 \\
\hline & $\mathrm{HLTH}+\mathrm{ED}$ & 1.45 & 0.63 & 207 & & $\mathrm{HLTH}+\mathrm{ED}$ & 1.82 & 0.74 & 205 \\
\hline & STEM & 1.60 & 0.66 & 42 & & STEM & 1.88 & 0.86 & 42 \\
\hline$F(3,432)=1.47, p=0.22$ & Total & 1.51 & 0.64 & 436 & $F(3,427)=0.60, p=0.61$ & Total & 1.84 & 0.75 & 431 \\
\hline \multirow{4}{*}{$\begin{array}{l}\text { Sorting and putting books back on } \\
\text { the shelves }\end{array}$} & $\mathrm{AH}+\mathrm{SS}$ & 1.50 & 0.79 & 72 & \multirow{4}{*}{$\begin{array}{l}\text { Analyzing the effectiveness of library } \\
\text { services and programs }\end{array}$} & $\mathrm{AH}+\mathrm{SS}$ & 1.67 & 0.68 & 70 \\
\hline & BUS & 1.54 & 0.78 & 116 & & BUS & 1.72 & 0.73 & 113 \\
\hline & HLTH+ED & 1.53 & 0.70 & 207 & & HLTH+ED & 1.71 & 0.73 & 203 \\
\hline & STEM & 1.44 & 0.63 & 43 & & STEM & 1.65 & 0.69 & 43 \\
\hline$F(3,434)=0.23, p=0.88$ & Total & 1.52 & 0.73 & 438 & $F(3,425)=0.15, p=0.93$ & Total & 1.70 & 0.71 & 429 \\
\hline \multirow[t]{4}{*}{ Evaluating student learning } & $\mathrm{AH}+\mathrm{SS}$ & 2.29 & 0.82 & 66 & \multirow{4}{*}{$\begin{array}{l}\text { Picking up trash/ } \\
\text { cleaning the library }\end{array}$} & $\mathrm{AH}+\mathrm{SS}$ & 2.73 & 1.10 & 67 \\
\hline & BUS & 2.20 & 0.84 & 116 & & BUS & 2.41 & 1.05 & 115 \\
\hline & HLTH+ED & 2.21 & 0.91 & 199 & & $\mathrm{HLTH}+\mathrm{ED}$ & 2.41 & 1.05 & 199 \\
\hline & STEM & 2.23 & 0.81 & 39 & & STEM & 2.49 & 1.05 & 41 \\
\hline$F(3,416)=0.18, p=0.91$ & Total & 2.22 & 0.87 & 420 & $F(3,418)=1.72, p=0.16$ & Total & 2.47 & 1.06 & 422 \\
\hline
\end{tabular}

Note: Response options were 1=Frequently, 2=Sometimes, 3=Rarely, and 4=Never. "Not Sure" was also an option but was not included in the analysis. 
Table 11. Please drag and drop the following reasons librarians chose to become librarians 1-9, where 1 is the top reason that librarians want to be librarians (Q11, $n=445$ ).

\begin{tabular}{|c|c|c|c|c|c|c|c|c|c|c|c|c|c|c|c|}
\hline & \multicolumn{3}{|c|}{ ARTS+SS } & \multicolumn{3}{|c|}{ BUS } & \multicolumn{3}{|c|}{ HLTH+ED } & \multicolumn{3}{|c|}{ STEM } & \multicolumn{3}{|c|}{ Total } \\
\hline & $M$ & sd & $\mathbf{N}$ & $M$ & sd & $\mathbf{N}$ & $M$ & sd & $\mathbf{N}$ & $M$ & sd & $\mathbf{N}$ & $M$ & sd & $\mathbf{N}$ \\
\hline $\begin{array}{l}\text { they want to work } \\
\text { in the university }\end{array}$ & & & & & & & & & & & & & & & \\
\hline library environment & 3.54 & 1.88 & 72 & 3.00 & 1.90 & 116 & 3.50 & 1.99 & 202 & 3.63 & 2.11 & 43 & 3.38 & 1.97 & 433 \\
\hline they like books & 2.87 & 1.74 & 72 & 3.09 & 2.07 & 116 & 2.98 & 2.06 & 202 & 3.09 & 1.57 & 43 & 3.00 & 1.96 & 433 \\
\hline attractive wages & & & & & & & & & & & & & & & \\
\hline and benefits & 7.31 & 1.62 & 72 & 6.74 & 1.98 & 116 & 7.42 & 1.61 & 202 & 7.21 & 2.11 & 43 & 7.20 & 1.79 & 433 \\
\hline they want to do & & & & & & & & & & & & & & & \\
\hline $\begin{array}{l}\text { library research } \\
\text { the prestige } \\
\text { accompanying the }\end{array}$ & 3.88 & 1.74 & 72 & 3.99 & 1.63 & 116 & 3.95 & 1.65 & 202 & 4.37 & 1.85 & 43 & 3.99 & 1.68 & 433 \\
\hline job & 7.44 & 1.11 & 72 & 6.61 & 1.67 & 116 & 7.07 & 1.39 & 202 & 7.14 & 1.42 & 43 & 7.02 & 1.46 & 433 \\
\hline they want to help & & & & & & & & & & & & & & & \\
\hline people & 2.69 & 1.83 & 72 & 2.99 & 1.90 & 116 & 3.03 & 1.81 & 202 & 2.81 & 1.98 & 43 & 2.94 & 1.85 & 433 \\
\hline they like working & & & & & & & & & & & & & & & \\
\hline with information & 3.49 & 1.49 & 72 & 4.42 & 2.02 & 116 & 3.70 & 1.88 & 202 & 3.40 & 1.69 & 43 & 3.83 & 1.88 & 433 \\
\hline they like working & & & & & & & & & & & & & & & \\
\hline with technology & 5.75 & 1.61 & 72 & 6.34 & 1.81 & 116 & 5.62 & 1.77 & 202 & 5.77 & 1.86 & 43 & 5.85 & 1.78 & 433 \\
\hline it's an easy job & 8.10 & 1.55 & 72 & 7.87 & 1.96 & 116 & 7.86 & 1.89 & 202 & 7.84 & 1.70 & 43 & 7.90 & 1.83 & 433 \\
\hline other & 9.93 & 0.26 & 72 & 9.94 & 0.33 & 116 & 9.88 & 0.84 & 202 & 9.74 & 1.38 & 43 & 9.89 & 0.75 & 433 \\
\hline
\end{tabular}


As these items had large standard deviations, results must be interpreted very cautiously. AH+SS and STEM ranked the reasons almost identically. HLTH+ED was the only college not to rank "they want to help people" as \#1, instead ranking it \#2, after "they like books." BUS ranked "They want to work in the university library" as \#2 (higher than the other groups) and "they like working with information" as \#5 (lower than the other groups).

BUS's average rankings were the most discrepant from the other college groups, as BUS had a slightly higher average rank for "they want to work in the university environment" $(M=3.00$ vs $\mathrm{AH}+\mathrm{SS}=3.54, \mathrm{HLTH}+\mathrm{ED}=3.50, \mathrm{STEM}=3.63)$, "the prestige accompanying the job," $(M=6.61$ vs $\mathrm{AH}+\mathrm{SS}=7.44, \mathrm{HLTH}+\mathrm{ED}=7.07, \mathrm{STEM}=7.14)$ and "attractive wages and benefits" $(M=6.74$ vs $\mathrm{AH}+\mathrm{SS}=7.31, \mathrm{HLTH}+\mathrm{ED}=7.42, \mathrm{STEM}=7.21)$ and a lower average rank for "they like working with information" $(M=4.42$ vs $\mathrm{AH}+\mathrm{SS}=3.49$, HLTH+ED=3.70, STEM=3.40) and "they like working with technology" $(M=6.34 \mathrm{vs}$ $\mathrm{AH}+\mathrm{SS}=5.75, \mathrm{HLTH}+\mathrm{ED}=5.62, \mathrm{STEM}=5.77)$. Between 190 and 231 students who chose a Subject Area responded to Q22, "Please read the following statements carefully and indicate your level of agreement. Remember, "Librarians" means academic librarians at a university like JMU]” (see Table 12). Response options were 1=Strongly agree, 2=Somewhat agree, $3=$ Neither agree nor disagree, $4=$ Somewhat disagree, and 5=Strongly disagree. Not Sure was an option but was not included in the analysis. ANOVAs revealed a statistically significant effect on two items, Librarians help me search the internet more effectively, $F(3,216)=3.84$, $p=.01$, and It is important to employ librarians of diverse ages, races, and gender, $F(3,220)=3.00, p=.03$. Post hoc comparisons using Tukey HSD were again conducted to determine which pairs of College groupings differed significantly $(p<.05)$ and effect size was calculated with Cohen's $d$. HLTH+ED students $(M=1.99, S D=0.96)$ more strongly agreed that "Librarians help me search the internet more effectively" than STEM students $(M=2.62$, $S D=1.24)(p=.03)$ with a significant effect of -.57 (medium). AH+SS students $(M=1.63$, 
$S D=1.04$ ) more strongly agreed that "It is important to employ librarians of diverse ages, races, and gender" than STEM $(M=2.33 S D=1.02)(p=.03)$ with an effect size of -.41 (medium).

Overall, we did not find meaningful differences by Subject Area across this set of items. The items with $a \geq .5$ mean difference did not seem to relate to one another, nor do we have hypotheses about why these differences would exist or implications for practice. Furthermore, the disciplinary averages all fell into broad agreement or disagreement.

Three hundred and eight students responded to the question "Why don't you like to ask librarians questions?” (Q18) for a total of 358.5 coded references. Definitions for these codes are provided in Table 13. Across the Subject Areas, HLTH+ED had the most respondents (132), followed by BUS (91), AH+SS (56), and STEM (29). A chi-square test of independence was conducted on the major categories revealed by the overall study ${ }^{3}$ and college groups to look for evidence of association. The chi-square test was invalid because $41 \%$ of cells had an expected count less than 5, and the data was too complex for a Fisher's Exact Test; therefore, we manually examined the data for descriptive trends.

STEM students mentioned Library as Place more often than the other groups (13\% compared with $8 \%$ for HLTH+ED, $7 \%$ for BUS, and $6 \%$ for AH+SS). "Lack of Need" was mentioned most frequently by three groups and was a close second by the fourth (AH+SS), even as it showed noticeable differences in the percentage of mentions (See Figure 6).

\footnotetext{
${ }^{3}$ Don't Think They Could Help, Lack of Need, Library as Place, Non-Awareness, Preference, Shyness or Anxiety, They Do, Unavailability
} 
Looking at standardized residuals greater than the absolute value of $1.5,{ }^{4}$ the number of BUS students mentioning Lack of Need was higher than the expected count (standardized residual=2), while for ARTS students, it was lower (standardized residual=-1.8). Shyness or Anxiety was mentioned less frequently by BUS students (standardized residual=-2.4, and netting only $6 \%$ of mentions) than other colleges, especially $\mathrm{AH}+\mathrm{SS}$ ( $27 \%$ of mentions), and it was also ranked 1, 2, or 3 by colleges other than business, which ranked it sixth. The number of AH+SS students mentioning Shyness or Anxiety was higher than the expected count ( standardized residual=2.6), as was Non-Awareness (standardized residual=1.7). Twelve percent of HLTH+ED students and $10 \%$ business students indicated they DO like to ask librarians questions, rejecting the premise of the question.

\footnotetext{
${ }^{4}$ Except for STEM, which had such a small group size that differences between expected and actual counts were often just one or a few students.
} 
Table 12. Please read the following statements carefully and indicate your level of agreement. Remember, "Librarians" means academic librarians at a university like James Madison University (Q22).

\begin{tabular}{|c|c|c|c|c|c|c|c|c|c|}
\hline & Subject & $M$ & sd & $\mathbf{N}$ & & Subject & $M$ & sd & $N$ \\
\hline \multirow[t]{4}{*}{ Librarians like helping students } & $\mathrm{AH}+\mathrm{SS}$ & 1.31 & 0.53 & 35 & \multirow[t]{4}{*}{ Librarians have difficult jobs } & $\mathrm{AH}+\mathrm{SS}$ & 2.44 & 0.84 & 32 \\
\hline & BUS & 1.41 & 0.59 & 41 & & BUS & 2.68 & 1.07 & 40 \\
\hline & HLTH+ED & 1.34 & 0.52 & 133 & & HLTH+ED & 2.34 & 0.90 & 129 \\
\hline & STEM & 1.32 & 0.57 & 22 & & STEM & 2.62 & 1.12 & 21 \\
\hline$F(3,227)=0.29, p=0.83$ & Total & 1.35 & 0.54 & 231 & Welch's $F(3,58.246)=1.29, p=0.29$ & Total & 2.44 & 0.95 & 222 \\
\hline \multirow[t]{4}{*}{ Librarians are slow } & $\mathrm{AH}+\mathrm{SS}$ & 4.22 & 0.91 & 32 & \multirow{4}{*}{$\begin{array}{l}\text { Helping students is a librarian's \#1 } \\
\text { priority }\end{array}$} & $\mathrm{AH}+\mathrm{SS}$ & 2.21 & 1.20 & 34 \\
\hline & BUS & 3.85 & 1.13 & 41 & & BUS & 1.95 & 1.05 & 41 \\
\hline & HLTH+ED & 3.95 & 1.02 & 129 & & HLTH+ED & 2.07 & 0.90 & 131 \\
\hline & STEM & 3.48 & 0.98 & 21 & & STEM & 2.27 & 0.98 & 22 \\
\hline$F(3,219)=2.32, p=0.08$ & Total & 3.93 & 1.03 & 223 & $F(3,224)=0.70, p=0.55$ & Total & 2.09 & 0.98 & 228 \\
\hline \multirow{4}{*}{$\begin{array}{l}\text { Librarians like helping students } \\
\text { with projects that are due } \\
\text { tomorrow }\end{array}$} & $\mathrm{AH}+\mathrm{SS}$ & 3.81 & 0.86 & 32 & \multirow{4}{*}{$\begin{array}{l}\text { Librarians have knowledge that is } \\
\text { practical to me }\end{array}$} & $\mathrm{AH}+\mathrm{SS}$ & 1.71 & 0.63 & 34 \\
\hline & BUS & 3.51 & 1.23 & 41 & & BUS & 1.83 & 0.70 & 41 \\
\hline & HLTH+ED & 3.52 & 1.24 & 131 & & HLTH+ED & 1.74 & 0.77 & 129 \\
\hline & STEM & 3.81 & 1.25 & 21 & & STEM & 1.86 & 0.83 & 22 \\
\hline Welch's $F(3,62.76)=1.07$ & Total & 3.59 & 1.19 & 225 & $F(3,222)=0.37, p=0.78$ & Total & 1.76 & 0.74 & 226 \\
\hline \multirow{4}{*}{$\begin{array}{l}\text { Librarians respect students' } \\
\text { intelligence }\end{array}$} & $\mathrm{AH}+\mathrm{SS}$ & 1.76 & 0.66 & 33 & \multirow[t]{4}{*}{ Librarians are friendly and pleasant } & $\mathrm{AH}+\mathrm{SS}$ & 1.74 & 0.67 & 34 \\
\hline & BUS & 1.54 & 0.67 & 41 & & BUS & 1.73 & 0.75 & 40 \\
\hline & HLTH+ED & 1.71 & 0.78 & 133 & & HLTH+ED & 1.73 & 0.76 & 130 \\
\hline & STEM & 1.77 & 0.81 & 22 & & STEM & 2.00 & 1.00 & 21 \\
\hline$F(3,225)=0.78, p=0.51$ & Total & 1.69 & 0.75 & 229 & $F(3,221)=0.78, p=0.50$ & Total & 1.76 & 0.77 & 225 \\
\hline \multirow{4}{*}{$\begin{array}{l}\text { Librarians help students learn to } \\
\text { do things themselves }\end{array}$} & $\mathrm{AH}+\mathrm{SS}$ & 1.70 & 0.95 & 33 & \multirow{4}{*}{$\begin{array}{l}\text { Librarians are experts with } \\
\text { technology }\end{array}$} & $\mathrm{AH}+\mathrm{SS}$ & 2.45 & 0.96 & 31 \\
\hline & BUS & 1.73 & 0.63 & 41 & & BUS & 2.45 & 0.93 & 40 \\
\hline & HLTH+ED & 1.72 & 0.77 & 133 & & HLTH+ED & 2.27 & 0.88 & 128 \\
\hline & STEM & 1.73 & 0.83 & 22 & & STEM & 2.62 & 1.02 & 21 \\
\hline$F(3,225)=0.01, p=1.00$ & Total & 1.72 & 0.78 & 229 & $F(3,216)=1.18, p=0.32$ & Total & 2.36 & 0.91 & 220 \\
\hline \multirow{4}{*}{$\begin{array}{l}\text { Librarians think people who } \\
\text { don't know the basics about the } \\
\text { library are stupid }\end{array}$} & $\mathrm{AH}+\mathrm{SS}$ & 4.13 & 1.01 & 32 & \multirow{4}{*}{$\begin{array}{l}\text { I would rather ask a female librarian } \\
\text { for help }\end{array}$} & $\mathrm{AH}+\mathrm{SS}$ & 2.71 & 1.07 & 31 \\
\hline & BUS & 4.08 & 1.19 & 40 & & BUS & 2.68 & 1.08 & 41 \\
\hline & HLTH+ED & 4.12 & 1.14 & 128 & & HLTH+ED & 2.93 & 1.08 & 128 \\
\hline & STEM & 3.77 & 1.41 & 22 & & STEM & 3.14 & 1.28 & 22 \\
\hline$F(3,218)=0.57, p=0.63$ & Total & 4.08 & 1.16 & 222 & $F(3,218)=1.17, p=0.32$ & Total & 2.87 & 1.10 & 222 \\
\hline
\end{tabular}

Note: Response options were 1, "Strongly agree," 2, "Somewhat agree," 3, "Neither agree nor disagree," 4, "Somewhat disagree," and 5, "Strongly disagree." Not Sure was an option but was not included in the analysis. 
Table 12 (continued). Please read the following statements carefully and indicate your level of agreement. Remember, "Librarians" means academic librarians at a university like James Madison University (Q22).

\begin{tabular}{|c|c|c|c|c|c|c|c|c|c|}
\hline & Subject & $M$ & $s d$ & $N$ & & Subject & $M$ & $s d$ & $N$ \\
\hline \multirow{4}{*}{$\begin{array}{l}\text { Librarians are too busy to help } \\
\text { students }\end{array}$} & $\mathrm{AH}+\mathrm{SS}$ & 4.00 & 1.08 & 32 & \multirow{4}{*}{$\begin{array}{l}\text { Librarians help me search the } \\
\text { internet more effectively }\end{array}$} & $\mathrm{AH}+\mathrm{SS}$ & 2.41 & 1.04 & 32 \\
\hline & BUS & 3.85 & 1.05 & 40 & & BUS & 2.05 & 0.97 & 41 \\
\hline & $\mathrm{HLTH}+\mathrm{ED}$ & 4.08 & 1.09 & 128 & & $\mathrm{HLTH}+\mathrm{ED}$ & 1.99 & 0.88 & 126 \\
\hline & STEM & 3.76 & 0.83 & 21 & & STEM & 2.62 & 1.02 & 21 \\
\hline$F(3,217)=0.85, p=0.47$ & Total & 4.00 & 1.06 & 221 & $F(3,216)=3.84, p=0.01$ & Total & 2.12 & 0.95 & 220 \\
\hline \multirow{4}{*}{$\begin{array}{l}\text { It is faster for me to figure out a } \\
\text { tough question myself rather } \\
\text { than ask a librarian }\end{array}$} & $\mathrm{AH}+\mathrm{SS}$ & 3.06 & 1.22 & 32 & \multirow{4}{*}{$\begin{array}{l}\text { Knowing more about a librarian's } \\
\text { education, skills, job, and } \\
\text { personality help me decide whether } \\
\text { or not to ask them for help }\end{array}$} & $\mathrm{AH}+\mathrm{SS}$ & 2.49 & 1.15 & 35 \\
\hline & BUS & 2.92 & 1.29 & 39 & & BUS & 2.61 & 1.09 & 41 \\
\hline & HLTH+ED & 3.10 & 1.14 & 130 & & $\mathrm{HLTH}+\mathrm{ED}$ & 2.37 & 1.07 & 127 \\
\hline & STEM & 2.73 & 1.28 & 22 & & STEM & 2.64 & 1.47 & 22 \\
\hline$F(3,219)=0.74, p=0.53$ & Total & 3.03 & 1.19 & 223 & $F(3,221)=0.70, p=0.56$ & Total & 2.46 & 1.13 & 225 \\
\hline \multirow{4}{*}{$\begin{array}{l}\text { Librarians understand students' } \\
\text { time pressures }\end{array}$} & $\mathrm{AH}+\mathrm{SS}$ & 2.58 & 1.15 & 33 & \multirow{4}{*}{$\begin{array}{l}\text { There are more female librarians } \\
\text { than male librarians }\end{array}$} & $\mathrm{AH}+\mathrm{SS}$ & 2.56 & 0.87 & 25 \\
\hline & BUS & 2.18 & 0.91 & 39 & & BUS & 2.21 & 0.98 & 39 \\
\hline & $\mathrm{HLTH}+\mathrm{ED}$ & 2.06 & 0.80 & 130 & & $\mathrm{HLTH}+\mathrm{ED}$ & 2.22 & 0.87 & 117 \\
\hline & STEM & 2.36 & 1.18 & 22 & & STEM & 2.06 & 0.94 & 18 \\
\hline Welch's $F(3,56.966)=2.24$ & Total & 2.19 & 0.93 & 224 & $F(3,195)=1.34, p=0.26$ & Total & 2.25 & 0.90 & 199 \\
\hline \multirow[t]{4}{*}{ Librarians are easy to talk to } & $\mathrm{AH}+\mathrm{SS}$ & 2.24 & 1.09 & 33 & \multirow{4}{*}{$\begin{array}{l}\text { I would be more willing to approach } \\
\text { a librarian of my own race or } \\
\text { ethnicity }\end{array}$} & $\mathrm{AH}+\mathrm{SS}$ & 3.42 & 1.09 & 33 \\
\hline & BUS & 2.11 & 0.88 & 37 & & BUS & 3.45 & 1.38 & 40 \\
\hline & $\mathrm{HLTH}+\mathrm{ED}$ & 1.92 & 0.81 & 128 & & $\mathrm{HLTH}+\mathrm{ED}$ & 3.32 & 1.22 & 124 \\
\hline & STEM & 2.52 & 1.29 & 21 & & STEM & 3.59 & 1.56 & 22 \\
\hline Welch's $F(3,54.95)=2.22$, & Total & 2.06 & 0.93 & 219 & Welch's $F(3,61.11)=0.27, p=0.85$ & Total & 3.39 & 1.26 & 219 \\
\hline \multirow{4}{*}{$\begin{array}{l}\text { Librarians are willing to change } \\
\text { their services to meet patrons' } \\
\text { needs }\end{array}$} & $\mathrm{AH}+\mathrm{SS}$ & 2.58 & 0.96 & 31 & \multirow{4}{*}{$\begin{array}{l}\text { There is enough diversity (race, } \\
\text { ethnicity, age, gender, etc.) among } \\
\text { librarians }\end{array}$} & $\mathrm{AH}+\mathrm{SS}$ & 3.38 & 1.24 & 24 \\
\hline & BUS & 2.49 & 0.94 & 39 & & BUS & 2.83 & 1.11 & 36 \\
\hline & $\mathrm{HLTH}+\mathrm{ED}$ & 2.44 & 1.00 & 126 & & $\mathrm{HLTH}+\mathrm{ED}$ & 2.95 & 1.03 & 109 \\
\hline & STEM & 2.81 & 0.93 & 21 & & STEM & 2.71 & 1.23 & 21 \\
\hline$F(3,213)=0.95, p=0.42$ & Total & 2.50 & 0.98 & 217 & $F(3,186)=1.66, p=0.18$ & Total & 2.95 & 1.10 & 190 \\
\hline \multirow{4}{*}{$\begin{array}{l}\text { Librarians use words that I don't } \\
\text { understand }\end{array}$} & $\mathrm{AH}+\mathrm{SS}$ & 3.97 & 1.10 & 30 & \multirow{4}{*}{$\begin{array}{l}\text { It is important to employ librarians } \\
\text { of diverse ages, races, and gender }\end{array}$} & $\mathrm{AH}+\mathrm{SS}$ & 1.63 & 0.73 & 35 \\
\hline & BUS & 3.41 & 1.04 & 39 & & BUS & 2.15 & 1.05 & 40 \\
\hline & $\mathrm{HLTH}+\mathrm{ED}$ & 3.44 & 1.08 & 126 & & $\mathrm{HLTH}+\mathrm{ED}$ & 1.91 & 0.96 & 128 \\
\hline & STEM & 3.25 & 1.25 & 20 & & STEM & 2.33 & 1.24 & 21 \\
\hline$F(3,211)=2.37, p=0.07$ & Total & 3.49 & 1.10 & 215 & $F(3,220)=3.00, p=0.03$ & Total & 1.95 & 0.99 & 224 \\
\hline \multirow{4}{*}{$\begin{array}{l}\text { Librarians know what they're } \\
\text { doing }\end{array}$} & $\mathrm{AH}+\mathrm{SS}$ & 1.56 & 0.89 & 34 & & & & & \\
\hline & BUS & 1.95 & 1.11 & 40 & & & & & \\
\hline & $\mathrm{HLTH}+\mathrm{ED}$ & 2.05 & 1.20 & 130 & & & & & \\
\hline & STEM & 1.86 & 1.15 & 21 & & & & & \\
\hline$F(3,221)=1.74, p=0.16$ & Total & 1.94 & 1.15 & 225 & & & & & \\
\hline
\end{tabular}


Table 13. Definitions for student responses to the question “Why don't you like to ask librarians questions?” (Q18, $n=308)$.

\begin{tabular}{|l|l|l|}
\hline Category & Description & Example responses in student survey (Q18) \\
\hline Don't Think They Could Help & $\begin{array}{l}\text { Assumptions that librarians would not have the } \\
\text { right expertise }\end{array}$ & "My work is too specific for them to assist" \\
\hline Lack of Need & Faculty feeling like they don't need help & "I don't need help" \\
\hline Library As Place & About the library as a building, as a place & $\begin{array}{l}\text { "I don't often go to the library and because online } \\
\text { resources are very easy to find" }\end{array}$ \\
\hline Non-Awareness & $\begin{array}{l}\text { Not realizing that librarians could help; distinct } \\
\text { from being unsure what to ask- }\end{array}$ & $\begin{array}{l}\text { "Don't know who/where they are" } \\
\text { "I do not know which people are librarians" }\end{array}$ \\
\hline Preference & $\begin{array}{l}\text { Specific choices or inclinations for getting help or } \\
\text { information }\end{array}$ & "I want to try to do it myself" \\
\hline Shyness or Anxiety & $\begin{array}{l}\text { Emotional responses to asking for help. Includes } \\
\text { fear of looking stupid, intimidation, awkwardness, } \\
\text { etc. }\end{array}$ & $\begin{array}{l}\text { "Afraid to sound dumb" } \\
\text { "Nervousness, social awkwardness" }\end{array}$ \\
\hline They Do & $\begin{array}{l}\text { Rejections of the premise of the question-they do } \\
\text { like to ask librarians questions }\end{array}$ & "I never mind asking questions" \\
\hline Unavailability & $\begin{array}{l}\text { Not being able to find librarians or having difficulty } \\
\text { contacting them; distinct from not being aware } \\
\text { that librarians could help }\end{array}$ & $\begin{array}{l}\text { "They are normally not there at night time" } \\
\text { "Couldn't find one" }\end{array}$ \\
\hline
\end{tabular}


Figure 6. "Why don't you like to ask librarians questions" (Q18, $n=308,358.5$ coded references).

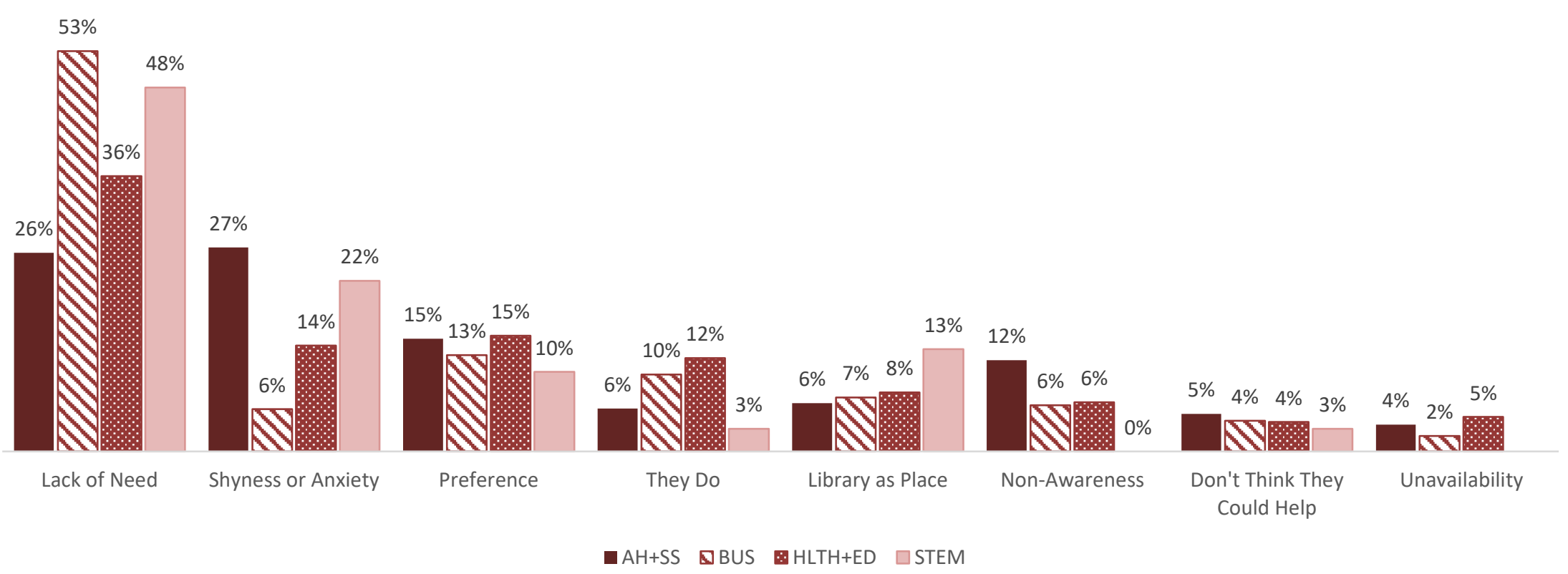


Two hundred and eighty-five students responded to the question "Why do you like to ask librarians questions?" (Q19) for a total of 477 coded references. Across the Subject Areas, HLTH+ED had the most respondents (121), followed by BUS (85), AH+SS (53), and STEM (26). Definitions for the categories coded are provided in Table 14. A chi-square test of independence was conducted on the major categories revealed by the overall study ${ }^{5}$ and college groups to look for evidence of association; no evidence was found $X^{2}(21, N=477)=$ 32.14 $\mathrm{p}=0.06$ ). Looking at standardized residuals to explore the data (absolute value greater than 1.5), however, suggests a lower probability for AH+SS students' responses to be coded "Need Help" than the other groups (standardized residual=-1.7); a lower probability for BUS students' responses to have been coded "Interpersonal Skills" (standardized residual=-1.6) and a higher probability for HLTH+ED students' responses to have been coded Interpersonal Skills (standardized residual=1.6) or Stumped or Lost (standardized residual=1.9).

Table 14. Definitions for coding student responses to the question "Why do you like to ask librarians questions?" (Q19, $n=285)$.

\begin{tabular}{|l|l|l|}
\hline Category & Description & $\begin{array}{l}\text { Example responses in student survey } \\
\text { (Q19) }\end{array}$ \\
\hline $\begin{array}{l}\text { Easier or More } \\
\text { Efficient }\end{array}$ & Saving time or effort & $\begin{array}{l}\text { "They make finding resources easier" } \\
\text { "I can find the answer a lot faster" }\end{array}$ \\
\hline Expertise & $\begin{array}{l}\text { Skills in finding information and using it, } \\
\text { possibly as part of a formal research } \\
\text { process. }\end{array}$ & $\begin{array}{l}\text { "I'm often confused when doing } \\
\text { research" } \\
\text { "If I need to find something" }\end{array}$ \\
\hline Good Experience & $\begin{array}{l}\text { Past experiences that were helpful or } \\
\text { useful }\end{array}$ & $\begin{array}{l}\text { "In the past, they were helpful in } \\
\text { helping me find the right books for my } \\
\text { research papers in various subjects" } \\
\text { "They are always extremely helpful" }\end{array}$ \\
\hline $\begin{array}{l}\text { Interpersonal } \\
\text { Skills }\end{array}$ & $\begin{array}{l}\text { Communication skills, customer service } \\
\text { skills, social skills, or personal qualities } \\
\text { such as "patient" or "intelligent" }\end{array}$ & $\begin{array}{l}\text { "They're very friendly and helpful" } \\
\text { "They're nice" }\end{array}$ \\
\hline Need Help & $\begin{array}{l}\text { A general need for information or } \\
\text { assistance }\end{array}$ & $\begin{array}{l}\text { "So I can get help" } \\
\text { "They might help me" }\end{array}$ \\
\hline Resources & $\begin{array}{l}\text { Materials mentioned generically } \\
\text { (holdings, resources, stuff, etc.) or }\end{array}$ & $\begin{array}{l}\text { "To find a book" } \\
\text { "To check out materials" }\end{array}$ \\
\hline
\end{tabular}

${ }^{5}$ Easier or More Efficient, Expertise, Good Experience, Interpersonal Skills, Need Help, Resources, Stumped or Lost, They Don't 


\begin{tabular}{|l|l|l|}
\hline & $\begin{array}{l}\text { specifically (data, articles, books, films, } \\
\text { etc.); Includes the concept of collection } \\
\text { management. Often also coded at } \\
\text { expertise in locating/accessing } \\
\text { information }\end{array}$ & \\
\hline Stumped or Lost & $\begin{array}{l}\text { Being stuck or having no idea how to } \\
\text { start; more pointed than references to } \\
\text { generally wanting or needing help }\end{array}$ & $\begin{array}{l}\text { "I have no other option" } \\
\text { "I'm really stuck" }\end{array}$ \\
\hline They Don't & $\begin{array}{l}\text { Rejections of the premise of the question } \\
\text { - they don't ask librarians questions }\end{array}$ & $\begin{array}{l}\text { "I don't ask questions" } \\
\text { "I have never spoken to a librarian" }\end{array}$ \\
\hline
\end{tabular}

Sorting the major categories by Subject Area showed a few differences in terms of overall rank and in the percentage of students mentioning something in the major category, but none of these differences were statistically significant (See Figure 7). The perceived Expertise of librarians was mentioned as the top reason to ask for help among all four groups, though HLTH+ED students mentioned it less frequently than the others (32\% compared to $44 \%$ for STEM, $41 \%$ for AH+SS, and $40 \%$ for BUS). HLTH+ED and BUS students mentioned "Need Help" second most frequently as a reason to ask (16\% and 15\%, respectively). HLTH+ED students were far more likely than other groups to mention asking for help when "Stumped or Lost" (7\% compared to 3\% for AH+SS, $2 \%$ for BUS, and $1 \%$ for STEM). STEM students more frequently mentioned asking for help because it was "Easier or More Efficient" than the other groups (12\% as compared to $7 \%$ for AH+SS and HLTH+ED, and $4 \%$ for BUS). Resources were the primary reason that AH+SS students mentioned that they asked for help (16\% compared with $14 \%$ for BUS and $10 \%$ for both HLTH+ED and STEM). Though BUS students mentioned librarians' Interpersonal Skills as valuable to themselves (tied with STEM at 17\%, compared to the other groups at 11\%), they mentioned it less frequently than the other groups as a reason to ask for help (7\% compared with $16 \%$ for HLTH+ED and $11 \%$ for both AH+SS and STEM). Business students also were most likely to mention that they actually don't ask for help (13\% compared with 9\% for STEM and $8 \%$ for both $\mathrm{AH}+\mathrm{SS}$ and HLTH+ED). 
Figure 7. "Why do you like to ask librarians questions" (Q19, $n=285,477$ coded references).

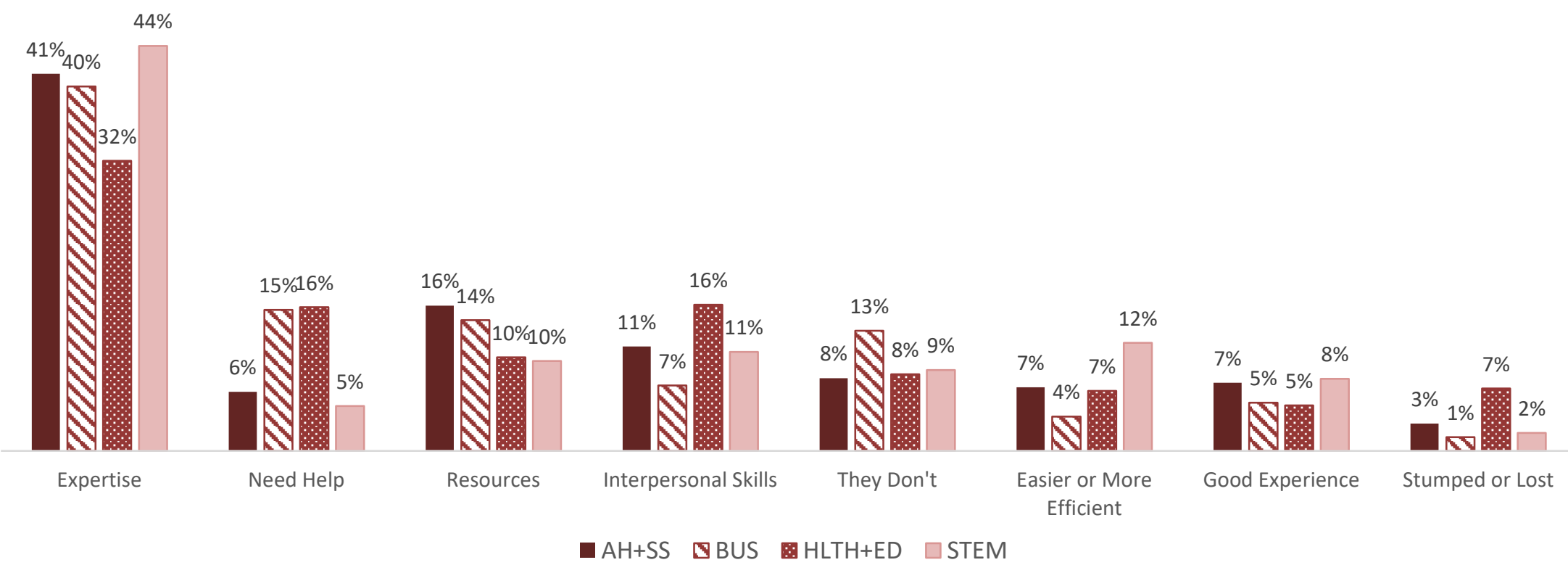




\section{Discussion}

As a reminder, the extent to which this single-institution study's findings might be generalizable to other schools is unknown. Furthermore, generalizability to JMU's population is also limited by the factors identified in the Demographics section, most notably the overrepresentation of Seniors in the Health Sciences. The differences in Subject Area group sizes, most notably the smaller sample of STEM students, also limited analysis, a frustration cited by previous research (Catalano \& Phillips, 2016). However, the study's findings provide possible insights to explore for local practice and might serve as inspiration for future research intending to examine differences across subject areas.

Our first research question was, "Are there differences by gender identity in how undergraduate students perceive academic librarians?" We found no evidence in our sample to support differences between males and females, which aligns with other recent research (Albarillo, 2018; LeMaistre, et al., 2018). The different proportion in our respondents' gender demographics as compared to the institution could suggest either that male and female undergraduates have different relationships with the libraries, or with respect to survey response. Specific hypotheses should be developed before pursuing further study of gender differences. In response to calls for research into trans and gender non-conforming populations (Matheson et al., 2020), we would suggest that future research (perhaps of a qualitative nature) investigate the smaller population of trans and gender-nonconforming students, to inform both library services and further diversity in the profession. We would also advise researchers (including ourselves) to check with trans and gender-nonconforming people in the target population to determine specific response options (see discussion by Spiel, Haimson, \& Lottridge, 2019), as language changes over time.

In response to our second research question, "Are there differences among subject areas in how undergraduate students perceive academic librarians," we found only five 
statistically significant differences among Subject Areas across the 74 survey items we analyzed. Spurious reasons for the lack of significant difference could include the way we created Subject Area groups; however, if this were the case, we would have at least expected BUS, an intact disciplinary group, to show more differences from the other groups than it did. One of the significant differences was that AH+SS students were more likely than STEM (and non-significantly more likely than the other Subject Areas) to credit librarians with their success. AH+SS also seemed to have a little more of a sense of librarians' professional duties than the other Subject Areas, with two significant items and a non-significant item. Further discussion of other notable non-significant differences will be discussed in the section on local practice.

In response to our third research question, "In what ways do students majoring in business differ from other majors in their perceptions of academic librarians?", we only found two significant differences between BUS and other colleges: BUS students perceived librarians create subject guides less frequently than did HLTH+ED students, and BUS students were more likely than AH+SS students to perceive librarians support computers/printers/photocopiers. These and other notable non-significant differences will be discussed in the section on local practice.

Given the overall lack of statistical significance and of large mean differences, the richest discussion surrounds our fourth research question, "How might differences affect local practice of librarianship?" While individual items might not have shown large differences by Subject Area, there were some trends across the survey instrument (and in some cases, in concert with previous research) that suggest possible explorations for our liaison librarians or for future research to investigate. 
It is notable that students' responses to both the What is Valuable questions did not differ significantly by Subject Area. Nor did we notice many descriptive differences. However, we found it intriguing that STEM students at JMU might be more likely to find Resources of value to the University than to themselves, and that JMU business students might be more likely than other majors to value the Interpersonal Skills of librarians to themselves and to the university.

The differences in how participants viewed the value of librarians' Expertise and Resources might help liaison librarians at JMU consider how to frame their outreach to students. For example, only $21 \%$ of STEM mentions indicated students personally valued librarian's Research skills (Q16). This might indicate a difference in how those disciplines use that term; STEM majors might view the term "research" through the lens of laboratory research (Kirker \& Stonebraker, 2019, p. 9), which they would not expect librarians to be skilled in. Emphasizing Locating \& Accessing Information as a reason that students might consult a librarian could be more effective for our STEM liaisons. Conversely, BUS students were the least likely across Subject Areas to mention Expertise with Locating \& Accessing Information (12\% of mentions) as valuable to the university (Q17), which might reflect a belief that most people are already self-sufficient in seeking information and "may actually be unaware of the extent to which librarians can help ... in facilitating the discovery of information" (Jameson et al., 2019, p. 380). For example, business students at JMU often are unaware they can download several years of company financial data from the database Mergent Online and instead spend time inefficiently creating their own spreadsheets from annual 10K reports available via the United States Securities and Exchange Commission. The business librarian could help them locate and access this information more efficiently. Ultimately, further research is needed to determine whether JMU students, particularly those 
in business disciplines, might overestimate or be overconfident in their abilities to Locate \& Access Information, as $64 \%$ of past studies about information literacy (IL) skills demonstrated in Khalid Mahmood's systematic review (2016, p. 204.) Mahmood noted that business was one of the largest subject groups in his review, with seven of eight studies showing an overestimation of IL skills (p. 205). Adapting the instrument from Pinto and Sales (2015) might be a useful strategy for our institution to try to determine what interventions are needed in business disciplines, if any.

In another examination of terminology, the Resources that participants mentioned in Q16 might help JMU liaisons assess and/or improve the effectiveness of their IL instruction. BUS students mentioned Books as a skill that librarians have that is valuable to them even more frequently than did the $\mathrm{AH}+\mathrm{SS}$ students ( $81 \%$ and $70 \%$ respectively), even though the latter subject area is traditionally assumed to be more reliant on books. STEM students mentioned Articles \& Journals most frequently among the groups (17\%, compared to $12 \%$ among HLTH+ED students and 7\% among AH+SS), while BUS students failed to mention them at all. While these results might reflect curricular priorities, it also could suggest that undergraduates in some Subject Areas at JMU might not fully use or understand common terms used in library instruction such as database or journal, as observed by Schaub et al. (2017), and as a result they don't see how those resources fit into their academic and/or professional preparation. Another potential explanation is that BUS students might believe that they no longer need to use Books to complete their assignments, preferring the quick access and shorter information resources available online. Therefore, if librarians are skilled in finding books, but books are not an information source that BUS students use, that might explain the higher percentage of "Lack of Need" or "They Don't" responses from business students than the other Subject Areas in Q18 and Q19. Business students also ranked "they 
like working with information" lower than other groups as a reason that librarians pursue this profession, so it's possible that, as (Fagan et al., 2021c) concluded, "Strong mental linkages between librarians, books, and the physical library might be a barrier to identifying librarians as relevant allies in students' academic success" (p. 35). This barrier might be especially high in business areas where industry and marketing reports, financial and economic data, and business-focused media are resources more frequently used than books. It might be worth exploring whether liaisons to business areas should move away from the title librarian in order to help students better realize that academic librarians' expertise in finding information extends to data, reports, and articles. Analysing the titles of positions that require a master's degree in library and/or information science (MLIS) at corporations, think tanks, and nonprofits could offer alternatives. A few such jobs posted on the American Library Association's JobsList and Indeed in July 2021 were Senior Information Services Analyst, Information Consultant, Information Specialist, and Research Analyst. Though a small sample, these could be a springboard for an investigation into whether librarians at higher education institutions should relinquish the outward-facing title "librarian" in favor of a descriptive title that is more meaningful to born-digital students. Future research should examine the implications of such a move.

Although it might be tempting for librarians to assume the success of IL programs or outreach efforts are the primary factors that determine whether students recognize our value and seek our help, we shouldn't overlook the fact that some of that behavior might be influenced by the types of students drawn to certain academic majors. Vedel (2016) synthesized the findings of 11 studies that examined students in different majors and their five-factor model (FFM) personality traits: Neuroticism, Extraversion, Openness to Experience, Agreeableness, and Conscientiousness (citing McCrae \& Costa, 1992). Kell 
(2018) summarized some of the adjectives that describe the FFM traits (p. 1239) on both ends of their continuum.

- Agreeableness: Highly agreeable people might be described as "considerate, generous, and kind," and highly disagreeable people might be described as "selfish, cold, and hostile."

- Conscientiousness: Highly conscientious people might be described as "organized, responsible, and hardworking," and highly unconscientious people might be described as "extravagant, careless, and impractical."

- Extroversion: Highly extroverted people might be described as "talkative, assertive, and energetic," and highly introverted people might be described as "timid, unadventurous, and inactive."

- Neuroticism: Highly neurotic people might be described as "emotional, nervous, and tense," and highly emotionally stable people might be described as "calm, relaxed, and contented."

- Openness to Experience: People scoring high on openness might be described as “imaginative, creative, and curious," and people scoring low on openness might be described as "unsophisticated, unreflective, and shallow."

In the studies that Vedel (2016) reviewed, Arts and Humanities students scored consistently high on Neuroticism; while Economics and Business students scored consistently lower than other groups (p. 7). Our findings reflect these, with Shyness/Anxiety being a reason not to ask question for $\mathrm{AH}+\mathrm{SS}$ students but not for BUS students. Liaisons to our $\mathrm{AH}+\mathrm{SS}$ subject areas might want to consider how they could put anxious students more at ease to facilitate more help-seeking behavior. But that might be less of a concern for business liaisons. 
Those same studies showed Law, Business, and Economics scored consistently lower than other groups on Agreeableness (Vedel, 2016). One facet of the AgreeablenessAntagonism continuum is modesty and its converse, arrogance (Lynam \& Miller, 2019, p. 119). BUS students had the smallest percentage of mentions of asking questions because it would be easier or more efficient or because they were stumped or lost. Business students were also the most likely to explicitly mention that they don't ask for help on the "Why do you ask" question, even though they were the most likely group to mention librarians' interpersonal skills being valuable. Taken together, these responses might indicate a greater overestimation among BUS students in their own knowledge or abilities, described by Cowan et al. (2019) as contributing components of "individual arrogance" (p. 426). As discussed earlier, further investigation into the IL skills of JMU's business students could confirm whether this personality trait might play a role in how to approach outreach and instruction for liaisons working with business disciplines. Cowan et al., (2019), in discussing how to change the beliefs of an arrogant person, suggested "provok[ing] further thought in a way that does not make the person defensive" (p. 439) and suggested asking the arrogant person "to reflect on and explain how those ideas work" rather than arguing against them (citing Fernbach, et al., 2013).

Several studies in the library and information science field appear to analyze how Big Five personality traits affect how students seek information (Al-Samarraie et al., 2017; Heinström et al., 2014; Kim et al., 2014; Schmidt \& Wolff, 2016; Zhang et al., 2021), and one examines them particularly in the context of using libraries (Halder et al., 2010). There are also studies examining variables that affect academic help-seeking, or students' "engagement in support that improves academic performance" (Bornschlegl et al., 2020, p. 487). In their systematic review, four studies specifically examined the relationship between 
personality traits and academic help-seeking (Bidjerano \& Dai, 2007; Ghyasi et al., 2013; Goodwin, 2009; Larose et al., 2009), with Extraversion being positively related in three studies and Neuroticism unrelated in three studies and negatively related in one study. Findings about Openness, Conscientiousness and Agreeableness were mixed: "They were positively related in one study and not related in two studies" (p. 508). Bornschlegl et al., also examined 67 studies that used gender as a variable, and found that "females were more likely to seek help than males, indicating that females have better attitudes towards help-seeking, have higher intentions to seek help, and seek more help in general" (p. 496).

Besides differences in students and curriculum, the data from our survey couldn't account for how perceptions of academic librarians might be affected by differences in the JMU liaison librarians' personalities, in the number of years they had been liaising with certain departments, in their approaches to work (e.g. use of subject guides), or in the information needs of a particular discipline (e.g. reliance on books instead of industry reports). In future studies, such evidence could be gathered using library data such as electronic resource authentication logs, courses receiving IL instruction, or student consultation statistics. This kind of data might allow researchers to create a variable that accounts for how stronger — or longer established—liaison relationships could impact perceptions of academic librarians.

The lack of notable difference across Subject Areas might mean that our survey instrument wasn't designed to pick up the nuances of how different majors use or interact with academic librarians. It might be tempting, as a result, for researchers to continue studying narrowly within fields (e.g., STEM students) or comparing only a couple of disciplines in a single study (e.g., literature majors vs. marketing majors). Despite the lack of statistical significance in this study, we believe it is imperative for librarians to devise studies 
that allow us to examine differences in library usage, perceptions, or academic impact across multiple majors or disciplines. As Anderson and Vega Garcia (2020) concluded, we must "recognize that students are diverse and do not represent a homogeneous block" (p. 478), and therefore, assessing perceptions or impact across an entire campus seems to limit the usefulness of what can be applied to local practice, particularly at universities or colleges without standardized information literacy instruction programs and/or organized around liaison librarian programs. Both Croxton and Moore (2020) and Scoulas and De Groote (2019) have recommended that academic majors be analyzed in future studies on the relationship between library usage and academic outcomes. In challenging the profession to do so, it's worth noting that variations in where majors fall across institutions can make these types of studies difficult to generalize. In hindsight, we should have asked students for their academic major instead of their JMU college, thus enabling us to group our majors into subject areas that would be more transferable across campuses and countries. Groupings unique to our campus, such as arts, humanities, and social science majors being split across four colleges, made it impossible to detect differences that might exist between arts majors and non-business social sciences majors at JMU, or to compare with other institutions. This latter concern also was raised by Anderson and Vega Garcia (2020). Future research could consider following the example of Jara et al. (2017) and using the fields from OECD's Frascati Manual Guidelines, which are intended to help standardize practice for countries to compare research and economic development data. The six fields of classification in the most recent manual are Natural Sciences, Engineering and Technology, Medical \& Health Sciences, Agricultural \& Veterinary Sciences, Social Sciences, and Humanities and the Arts (OECD, 2015, p. 59). Second-level classifications provided in the same table can help slot disciplines into appropriate fields. 


\section{Conclusion}

This study explored differences among subpopulations of undergraduate students of different genders and academic subjects in how they perceive academic librarians.

Ultimately, few significant differences were found:

- No evidence in our sample to support differences among male and female gender identities in $(R Q 1)$

- Five statistically significant differences among our four Subject Areas (RQ2), including greater understanding of librarians' duties and how they might impact a student's academic success by undergraduates studying Arts, Humanities and Social Sciences fields.

- Two significant differences between business students and the other subject areas (RQ3), including lower perceptions of librarians' role in creating subject guides and stronger perceptions of librarians supporting computers/printers/photocopiers.

These findings — in addition to trends observed across the survey instrumentthe following implications for practice at JMU (RQ4): Mitigating library anxiety through instruction or outreach is likely more of a concern for liaisons to arts, humanities and nonbusiness social sciences students; emphasizing librarians' expertise in Locating \& Accessing Information and Resources over their skills in Research might be more of a priority for liaisons to STEM areas; and overcoming students' overestimates of their information skills and ingrained perceptions that librarians are mostly experts in using books are of greatest importance to liaisons working with business fields. Overall, business students did not view academic librarians as either more or less relevant to their work or academic success than did students in the other Subject Areas studied (Arts, Humanities + Social Sciences, Health + 
Education, and STEM). Despite a lack of significant findings in this study, librarians should continue to explore ways to measure how students of different disciplines perceive academic libraries and/or librarians as valuable or impactful to their academic success.

\section{References}

Albarillo, F. (2018). Super-diversity and foreign-born students in academic libraries: A survey study. portal: Libraries and the Academy, 18(1), 59-91. https://doi.org/10.1353/pla.2018.0004

Allison, D. (2015). Measuring the academic impact of libraries. portal: Libraries and the Academy, 15(1), 29-40. https://doi.org/10.1353/pla.2015.0001

Al-Samarraie, H., Eldenfria, A., \& Dawoud, H. (2017). The impact of personality traits on users' information-seeking behavior. Information Processing \& Management, 53(1), 237-247. https://doi.org/10.1016/j.ipm.2016.08.004

Anderson, L., \& Vega García, S. (2020). Library usage, instruction, and student success across disciplines: A multilevel model approach. College \& Research Libraries, 81(3), 459. https://doi.org/10.5860/crl.81.3.459

Bickley, R., \& Corrall, S. (2011). Student perceptions of staff in the Information Commons: A survey at the University of Sheffield. Reference Services Review, 39(2), 223-243. https://doi.org/10.1108/00907321111135466

Bidjerano, T. \& Dai, D. Y. (2007) The relationship between the big-five model of personality and self-regulated learning strategies. Learning and Individual Differences, 17(1), 6981. https://doi.org/10.1016/j.lindif.2007.02.001

Bonnet, J. L., \& McAlexander, B. (2013). First impressions and the reference encounter: The influence of affect and clothing on librarian approachability. The Journal of Academic Librarianship, 39(4), 335-346. https://doi.org/10.1016/j.acalib.2012.11.025 
Bornschlegl, M., Meldrum, K., \& Caltabiano, N. J. (2020). Variables related to academic help-seeking behaviour in higher education - Findings from a multidisciplinary perspective. Review of Education, 8(2), 486-522. https://doi.org/10.1002/rev3.3196

Carroll, A. J., Corlett-Rivera, K., Hackman, T., \& Jinwang Zou. (2016). E-Book perceptions and use in STEM and non-STEM disciplines: A comparative follow-up study. portal: Libraries \& the Academy, 16(1), 131-162. https://doi.org/10.1353/pla.2016.0002

Catalano, A. J., \& Phillips, S. R. (2016). Information literacy and retention: A case study of the value of the library. Evidence Based Library and Information Practice, 11(4), 213. https://doi.org/10.18438/B82K7W

Çetin, Y., \& Howard, V. (2016). An exploration of the relationship between undergraduate students' library book borrowing and academic achievement. Journal of Librarianship and Information Science, 48(4), 382-388. https://doi.org/10.1177/0961000615572404

Cherry, E., Rollins, S. H., \& Evans, T. (2013). Proving our worth: The impact of electronic resource usage on academic achievement. College \& Undergraduate Libraries, 20(34), 386-398. https://doi.org/10.1080/10691316.2013.829378

Costa, P. T., \& McCrae, R. R. (1992). The five-factor model of personality and its relevance to personality disorders. Journal of Personality Disorders, 6(4), 343-359. https://doi.org/10.1521/pedi.1992.6.4.343

Cowan, N., Adams, E. J., Bhangal, S., Corcoran, M., Decker, R., Dockter, C. E., Eubank, A. T., Gann, C. L., Greene, N. R., Helle, A. C., Lee, N., Nguyen, A. T., Ripley, K. R., Scofield, J. E., Tapia, M. A., Threlkeld, K. L., \& Watts, A. L. (2019). Foundations of arrogance: A broad survey and framework for research. Review of General Psychology, 23(4), 425-443. https://doi.org/10.1177/1089268019877138 
Criado Perez, C. (2019). Invisible women: Exposing data bias in a world designed for men. Random House.

Croxton, R., \& Moore, A. (2020). Quantifying library engagement: Aligning library, institutional, and student success data. College \& Research Libraries, 81(3), 399-434. https://doi.org/10.5860/crl.81.3.399

Cummings, L. A., Larrivee, A., \& Vega, L. (2015). Comparing electronic vs print book preferences between students in the social sciences, the arts and STEM. Library Hi Tech News, 32(4), 1-4. https://doi.org/10.1108/LHTN-10-2014-0088

Ebijuwa, A. S., \& Mabawonku, I. (2019). Demographic variables and academic discipline as determinants of undergraduates' use of electronic library resources in federal universities in South-west, Nigeria. Library Philosophy and Practice, 1-21. https://digitalcommons.unl.edu/libphilprac/2164/

Fagan, J. (2003). Students' perceptions of academic librarians. The Reference Librarian, 37(78), 131-148. https://doi.org/10.1300/J120v37n78_09

Fagan, J. C., Ostermiller, H., Price, E., \& Sapp, L. (2020). Faculty perceptions of academic librarians: Experts, Connectors, and resource stewards. New Review of Academic Librarianship, 1-38. https://doi.org/10.1080/13614533.2020.1819354

Fagan, J. C., Ostermiller, H., Price, E., \& Sapp, L. (2021a). Librarian, faculty, and student perceptions of academic librarians: Study introduction and literature review. New Review of Academic Librarianship, 27(1), 38-75. https://doi.org/10.1080/13614533.2019.1691026

Fagan, J. C., Ostermiller, H., Price, E., \& Sapp, L. (2021b). Academic librarian perceptions of academic librarians: Building a foundation of shared understanding. New Review of 
Academic Librarianship, 27(2), 201-229.

https://doi.org/10.1080/13614533.2020.1765817

Fagan, J. C., Ostermiller, H., Price, E., \& Sapp, L. (2021c). Student perceptions of academic librarians and the librarian-faculty-student dynamic: Minding our gaps. New Review of Academic Librarianship, 1-47. https://doi.org/10.1080/13614533.2021.1906717

Fernbach, P. M., Sloman, S. A., Louis, R. St., \& Shube, J. N. (2013). Explanation fiends and foes: How mechanistic detail determines understanding and preference. Journal of Consumer Research, 39(5), 1115-1131. https://doi.org/10.1086/667782

Gaha, U., Hinnefeld, S., \& Pellegrino, C. (2018). The academic library's contribution to student success: Library instruction and GPA. College \& Research Libraries, 79(6), 737-746. https://doi.org/10.5860/crl.79.6.737

Ghyasi, M., Yazdani, M. \& Farsani, M. A. (2013). The relationship between personality types and self-regulated learning strategies of language learners. International Journal of Applied Linguistics and English Literature, 2(4), 74-82. https://doi.org/10.7575/aiac.ijalel.v.2n.4p.74

Goodwin, M. E. (2009). Gender role conflict, depression, and personality's effect on helpseeking behaviors, attitudes, and academic performance $(\mathrm{PhD}$ thesis, Iowa State University, Ames, IA). https://lib.dr.iastate.edu/etd/10645

Haigh, A. E. (2013). You can lead students to the library, but can you make them do research? The effect of syllabus design and content on undergraduates' perceptions and use of the academic library. Journal of Business \& Finance Librarianship, 18(1), 33-48. https://doi.org/10.1080/08963568.2012.737658

Halder, S., Roy, A., \& Chakraborty, P. K. (2010). The influence of personality traits on information seeking behaviour of students. Malaysian Journal of Library \& 
Information Science, 15(1), 41-53. Retrieved from

http://mjs.um.edu.my/index.php/MJLIS/article/view/6721

Heinström, J., Sormunen, E., \& Kaunisto-Laine, S. (2014). Spanning information behaviour across the stages of a learning task: Where do personality and approach to studying matter? Journal of Documentation, 70(6), 1076-1097. https://doi.org/10.1108/JD-02$\underline{2014-0041}$

Hernon, P., \& Pastine, M. (1977). Student perceptions of academic librarians. College and Research Libraries, 38(2), 129-139. https://doi.org/10.5860/crl_38_02_129

Jameson, J., Natal, G., \& Napp, J. (2019). Evolving and enduring patterns surrounding student usage and perceptions of academic library reference services. College \& Research Libraries, 80(3), 366-385. https://doi.org/10.5860/crl.80.3.366

Jara, M., Clasing, P., González, C., Montenegro, M., Kelly, N., Alarcón, R., Sandoval, A., \& Saurina, E. (2017). Patterns of library use by undergraduate students in a Chilean University. portal: Libraries and the Academy, 17(3), 595-615. https://doi.org/10.1353/pla.2017.0036

Kell, H. J. (2018). Personality assessment. In B. B. Frey (Ed.), The SAGE Encyclopedia of Educational Research, Measurement, and Evaluation (pp. 1239-1243). SAGE Publications, Inc. https://doi.org/10.4135/9781506326139

Kim, K.S., Sin, S.C. J., \& Tsai, T.I. (2014). Individual differences in social media use for information seeking. The Journal of Academic Librarianship, 40(2), 171-178. https://doi.org/10.1016/j.acalib.2014.03.001

Kirker, M. J., \& Stonebraker, I. (2019). Architects, renovators, builders, and fragmenters: A model for first year students' self-perceptions and perceptions of information literacy. 
The Journal of Academic Librarianship, 45(1), 1-8.

https://doi.org/10.1016/j.acalib.2018.10.009

Kot, F. C., \& Jones, J. L. (2015). The impact of library resource utilization on undergraduate students' academic performance: A propensity score matching design. College \& Research Libraries, 76(5), 566-586. https://doi.org/10.5860/crl.76.5.566

Krueger, S., \& Matteson, M. (2017). Serving transgender patrons in academic libraries. Public Services Quarterly, 13(3), 207-216. https://doi.org/10.1080/15228959.2017.1338543

Larose, S., Cyrenne, D., Garceau, O., Harvey, M., Guay, F. \& Desch^enes, C. (2009). Personal and social support factors involved in students' decision to participate in formal academic mentoring. Journal of Vocational Behavior, 74(1), 108-116. https://doi.org/10.1016/j.jvb.2008.11.002

LeMaistre, T., Shi, Q., \& Thanki, S. (2018). Connecting library use to student success. portal: Libraries and the Academy, 18(1), 117-140. https://doi.org/10.1353/pla.2018.0006

Lynam, D. R., \& Miller, J. D. (2019). The basic trait of antagonism: An unfortunately underappreciated construct. Journal of Research in Personality, 81, 118-126. https://doi.org/10.1016/j.jrp.2019.05.012

Mahmood, K. (2016). Do people overestimate their information literacy skills? A systematic review of empirical evidence on the Dunning-Kruger Effect. Comminfolit, 10(2), 199. https://doi.org/10.15760/comminfolit.2016.10.2.24

Matheson, M., Tait, E., \& Reynolds, S. (2020). Checking the pulse of LGBTIQ+ inclusion and representation in the academic library: A literature review. Journal of the 
Australian Library and Information Association, 69(1), 31-46.

https://doi.org/10.1080/24750158.2019.1686571

Mayer, J., Dineen, R., Rockwell, A., \& Blodgett, J. (2020). Undergraduate student success and library use: A multimethod approach. College \& Research Libraries, 81(3), 378398. https://doi.org/10.5860/crl.81.3.378

Mizrachi, D. (2015). Undergraduates' academic reading format preferences and behaviors. The Journal of Academic Librarianship, 41(3), 301-311. https://doi.org/10.1016/j.acalib.2015.03.009

OECD. (2015). Frascati Manual 2015: Guidelines for Collecting and Reporting Data on Research and Experimental Development. OECD. https://doi.org/10.1787/9789264239012-en

Pinto, M., \& Sales, D. (2015). Uncovering information literacy's disciplinary differences through students' attitudes: An empirical study. Journal of Librarianship and Information Science, 47(3), 204-215. https://doi.org/10.1177/0961000614532675

Renaud, J., Britton, S., Wang, D., \& Ogihara, M. (2015). Mining library and university data to understand library use patterns. The Electronic Library, 33(3), 355-372. https://doi.org/10.1108/EL-07-2013-0136

Samson, S. (2014). Usage of e-resources: Virtual value of demographics. The Journal of Academic Librarianship, 40(6), 620-625. https://doi.org/10.1016/j.acalib.2014.10.005

Schaub, G., Cadeno, C., Bravender, P., \& Kierkus, C. (2017). The language of information literacy: Do students understand? College \& Research Libraries, 78(3), 283. https://doi.org/10.5860/crl.78.3.283 
Schmidt, T., \& Wolff, C. (2016). Personality and information behavior in web search. Proceedings of the Association for Information Science and Technology, 53(1), 1-6. https://doi.org/10.1002/pra2.2016.14505301121

Scoulas, J.M., \& De Groote, S. L. (2019). The library's impact on university students' academic success and learning. Evidence Based Library \& Information Practice, 14(3), 2-27. https://doi.org/10.18438/eblip29547

Soria, K., \& Fransen, J. (2017). The impact of academic library resources on undergraduates' degree completion. College \& Research Libraries, 78(6), 812-823. https://doi.org/10.5860/crl.78.6.812

Soria, K. M., Fransen, J., \& Nackerud, S. (2013). Library use and undergraduate student outcomes: New evidence for students' retention and academic success. portal: Libraries and the Academy, 13(2), 147-164. https://doi.org/10.1353/pla.2013.0010

Soria, K. M., Fransen, J., \& Nackerud, S. (2017). Beyond books: The extended academic benefits of library use for first-year college students. College \& Research Libraries, 78(1), 8-22. https://doi.org/10.5860/crl.78.1.8

Spiel, K., Haimson, O., \& Lottridge, Danielle. (2019, July-August). How to do better with gender on surveys: A guide for HCI researchers. IX Interactions, XXVI.4, 62. https://interactions.acm.org/archive/view/july-august-2019/how-to-do-better-withgender-on-surveys

Stemmer, J. K., \& Mahan, D. M. (2016). Investigating the relationship of library usage to student outcomes. College \& Research Libraries, 77(3), 359-375. https://doi.org/10.5860/crl.77.3.359 
Thorpe, A., Lukes, R., Bever, D. J., \& He, Y. (2016). The impact of the academic library on student success: Connecting the dots. portal: Libraries and the Academy, 16(2), 373392. https://doi.org/10.1353/pla.2016.0027

Vedel, A. (2016, April). Big Five personality group differences across academic majors: A systematic review. Personality and Individual Differences, 92, 1-10. https://doi.org/10.1016/j.paid.2015.12.011

Weber, M. (2018, May 29). Alphabetical name ordering is discriminatory and harmful to collaborations. Impact of Social Sciences. https://blogs.lse.ac.uk/impactofsocialsciences/2018/05/29/alphabetical-nameordering-is-discriminatory-and-harmful-to-collaborations/

Wexelbaum, R. S. (2018). Do libraries save LGBT students? Library Management, 39(1/2), 31-58. https://doi.org/10.1108/LM-02-2017-0014

Wong, S. H. R., \& Webb, T. D. (2011). Uncovering meaningful correlation between student academic performance and library material usage. College \& Research Libraries, 72(4), 361-370. https://doi.org/10.5860/crl-129

Zhang, Z., Yao, X., Yuan, S., Deng, Y., \& Guo, C. (2021, April). Big five personality influences trajectories of information seeking behavior. Personality and Individual Differences, 173, 110631. https://doi.org/10.1016/j.paid.2021.110631 


\section{Appendix: Student Perceptions of Academic Librarians Survey Instrument}

IRB, protocol No. 17-0549

Note: for the purposes of this survey, the phrase "academic librarians" will refer to librarians who work in libraries at universities like James Madison University.

\section{You and your experience with librarians:}

1. I am a... -Selected Choice: First year (Freshman); Sophomore; Junior; Senior; Other

2. I identify as ... - Selected Choice: Female; Genderqueer or gender fluid; Male; Other [with optional text entry]; Prefer not to say

3. My major is within ... - Selected Choice: College of Arts \& Letters; College of Business; College of Education; College of Health and Behavioral Studies; College of Integrated Science \& Engineering; College of Science \& Math; College of Visual \& Performing Arts; My major is undeclared

4. How often have you consulted librarians in a public library?

\begin{tabular}{|l|c|c|c|c|c|}
\hline & $\begin{array}{c}\text { More than } \\
\text { once a } \\
\text { month }\end{array}$ & $\begin{array}{c}\text { About } \\
\text { once a } \\
\text { month }\end{array}$ & $\begin{array}{c}\text { Several } \\
\text { times per } \\
\text { year }\end{array}$ & $\begin{array}{c}\text { Less than } \\
\text { once per } \\
\text { year }\end{array}$ & Never \\
\hline $\begin{array}{l}\text { During } \\
\text { elementary } \\
\text { school (K-5)? }\end{array}$ & $\square$ & $\square$ & $\square$ & $\square$ & $\square$ \\
\hline $\begin{array}{l}\text { During middle } \\
\text { school (6-8)? }\end{array}$ & $\square$ & $\square$ & $\square$ & $\square$ & $\square$ \\
\hline $\begin{array}{l}\text { During high } \\
\text { school (9-12)? }\end{array}$ & $\square$ & $\square$ & $\square$ & $\square$ & $\square$ \\
\hline
\end{tabular}

5. How often did you consult your school's librarian?

\begin{tabular}{|l|c|c|c|c|c|c|}
\hline & $\begin{array}{c}\text { More } \\
\text { than } \\
\text { once a } \\
\text { month }\end{array}$ & $\begin{array}{c}\text { About } \\
\text { once a } \\
\text { month }\end{array}$ & $\begin{array}{c}\text { Several } \\
\text { times per } \\
\text { year }\end{array}$ & $\begin{array}{c}\text { Less than } \\
\text { once per } \\
\text { year }\end{array}$ & Never & $\begin{array}{c}\text { My } \\
\text { school } \\
\text { didn't } \\
\text { have a } \\
\text { librarian }\end{array}$ \\
\hline $\begin{array}{l}\text { During } \\
\text { elementary } \\
\text { school (K- } \\
\text { 5)? }\end{array}$ & $\square$ & $\square$ & $\square$ & $\square$ & $\square$ & $\square$ \\
\hline $\begin{array}{l}\text { During } \\
\text { middle } \\
\text { school (6- } \\
\text { 8)? }\end{array}$ & $\square$ & $\square$ & $\square$ & $\square$ & $\square$ & $\square$ \\
\hline
\end{tabular}




\begin{tabular}{|l|l|l|l|l|l|l|}
\hline $\begin{array}{l}\text { During high } \\
\text { school (9- } \\
\text { 12)? }\end{array}$ & $\square$ & $\square$ & $\square$ & $\square$ & $\square$ & $\square$ \\
\hline
\end{tabular}

6. To what extent, if any, do you think librarians helped you succeed?

\begin{tabular}{|l|c|c|c|c|c|}
\hline & $\begin{array}{c}\text { A great } \\
\text { deal }\end{array}$ & $\begin{array}{c}\text { A } \\
\text { moderate } \\
\text { amount }\end{array}$ & A little & None at all & Not sure \\
\hline $\begin{array}{l}\text { During } \\
\text { elementary } \\
\text { school (K-5)? }\end{array}$ & $\square$ & $\square$ & $\square$ & $\square$ & $\square$ \\
\hline $\begin{array}{l}\text { During middle } \\
\text { school (6-8)? }\end{array}$ & $\square$ & $\square$ & $\square$ & $\square$ & $\square$ \\
\hline $\begin{array}{l}\text { During high } \\
\text { school (9-12)? }\end{array}$ & $\square$ & $\square$ & $\square$ & $\square$ & $\square$ \\
\hline
\end{tabular}

7. How often have you consulted academic librarians during your college years? Selected Choice: More than once a month; About once a month; Several times per year; Less than once per year; Never

8. To what extent, if any, do you think librarians helped you succeed during your college education? -Selected Choice: A great deal; A lot; A moderate amount; A little; None at all; Not sure

\section{The librarian job:}

9. Please drag and drop the following reasons librarians chose to become librarians 1-9, where 1 is the top reason that librarians want to be librarians. You may write in another reason and rank it too.

- they want to work in the university library environment (scholarly, quiet, etc.)

- they like books

- attractive wages and benefits

- they want to do library research

- the prestige accompanying the job

- they want to help people

- they like working with information

- they like working with technology

- it's an easy job

- other

10. How often do you think academic librarians perform the following duties? Frequently; Sometimes; Rarely; Never; Not Sure

- Issuing library cards

- Helping users to find books

- Lending books, films, equipment to users 
- Processing fines

- Giving general directional help

- Buying books, journal and electronic materials

- Removing outdated books

- Creating Subject Guides

- Giving general help to students for research

- Giving subject-specific help to students for research

- Giving general help to faculty for research

- Sorting and putting books back on the shelves

- Evaluating student learning

- Creating online tutorials

- Repairing damaged materials

- Planning special events at the library

- Publishing research about the library profession

- Working in Starbucks

- Supporting library computers/printers/photocopiers

- Providing IT support for campus wi-fi

- Teaching research skills (in classes or one-on-one)

- Teaching software skills (in classes or one-on-one)

- Teaching copyright principles (in classes or one-on-one)

- Marketing library services and programs

- Analyzing the effectiveness of library services and programs

- Picking up trash/cleaning the library

11. In the JMU Libraries, can you tell which workers are librarians?

- Yes

- No

- Not sure

12. In the JMU Libraries, do you ever ask to speak to a librarian?

- Yes

- No

- Not sure

13. Do you think academic librarians are faculty at JMU??

- Yes

- No

- Not sure

14. Do you think academic librarians are faculty at every university?

- Yes

- No

- Not sure

15. How much do you think an entry-level JMU librarian makes per year?

- Less than $\$ 20,000$ 
- $\$ 20,000-\$ 29,999$

- $\$ 30,000-\$ 39,999$

- $\$ 40,000$ - $\$ 49,999$

- $\$ 50,000-\$ 59,999$

- $\$ 60,000-\$ 69,999$

- $\$ 70,000$ - $\$ 79,999$

- More than $\$ 80,000$

16. What skills do you think librarians have that are valuable to you? [multiline text entry box]

17. What skills do you think librarians have that are valuable to the university? [multiline text entry box]

18. Why don't you like to ask librarians questions? [multiline text entry box]

19. Why do you like to ask librarians questions? [multiline text entry box]

\section{Education:}

20. What do you think is the minimum level of educational qualifications required to be hired as an entry-level JMU librarian?

- High school degree

- Some college classes

- Bachelor's degree

- Master's degree

- More than one Master's degree

- Doctoral degree

- Multiple doctoral degrees

21. What do you think academic librarians learn in their library classes? Please write at least three topics you think are covered in library school classes: [multiline text entry box]

\section{General Opinions:}

22. Please read the following statements carefully and indicate your level of agreement. Remember, "Librarians" means academic librarians at a university like JMU:

Strongly agree; Somewhat agree; Neither agree nor disagree; Somewhat disagree; Strongly disagree, Not Sure

- Librarians like helping students

- Librarians are slow

- Librarians like helping students with projects that are due tomorrow

- Librarians respect students' intelligence

- Librarians help students learn to do things themselves

- Librarians think people who don't know the basics about the library are stupid 
- Librarians are too busy to help students

- It is faster for me to figure out a tough question myself rather than ask a librarian

- Librarians understand students' time pressures

- Librarians are easy to talk to

- Librarians are willing to change their services to meet patrons' needs

- Librarians use words that I don't understand

- Librarians know what they're doing

- Librarians have difficult jobs

- Helping students is a librarian's \#1 priority

- Librarians have knowledge that is practical to me

- Librarians are friendly and pleasant

- Librarians are experts with technology

- I would rather ask a female librarian for help

- Librarians help me search the internet more effectively

- Knowing more about a librarian's education, skills, job, and personality help me decide whether or not to ask them for help

- There are more female librarians than male librarians

- I would be more willing to approach a librarian of my own race or ethnicity

- There is enough diversity (race, ethnicity, age, gender, etc.) among librarians

- It is important to employ librarians of diverse ages, races, and gender

23. Any additional comments? [multiline text entry box] 